Máster Universitario en Diversidad Cultural

Un enfoque multidisciplinar y transfronterizo

Curso 2016-2017

\title{
MENORES EXTRANJEROS NO ACOMPAÑADOS EN LA CIUDAD AUTÓNOMA DE MELILLA \\ Desde el desarraigo a la inserción
}

Autora: Sara Conesa Ramos

Tutora: Bibinha Benbunan Bentata 


\section{AGRADECIMIENTOS}

A mi tutora por su eterna paciencia, dedicación y esfuerzo. Por estar conmigo en todo momento, contestando a todos los correos y mensajes de manera inmediata. Por sus enseñanzas, siempre desde el cariño.

A todos los participantes, por los buenos ratos que hemos pasado haciendo las entrevistas y hacerme partícipes de sus historias. Sin ellos este trabajo no habría sido posible.

A mi familia, en especial a mi marido, mis hijos y mis padres, por haber entendido tantas ausencias y nervios durante este periodo. Haber sido comprensivos con mis nervios y en ocasiones, mal humor. Todo lo que hago es pensando en vosotros. 


\section{ÍNDICE}

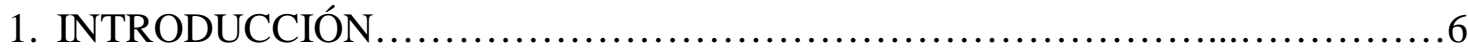

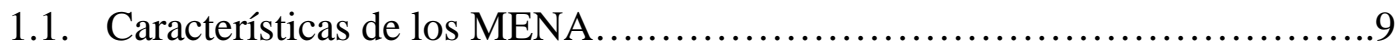

1.2. Factores relacionados con la migración de estos menores .....................10

1.3. Fuentes de información de los menores extranjeros no acompañados..........11

1.4. Factores que dificultan la integración........................................12

1.5. Factores que promueven la adecuada integración.............................14

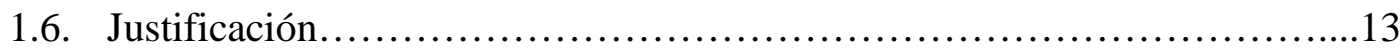

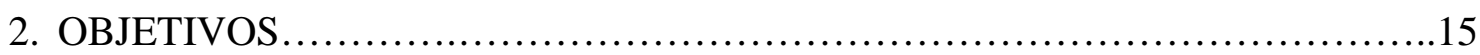

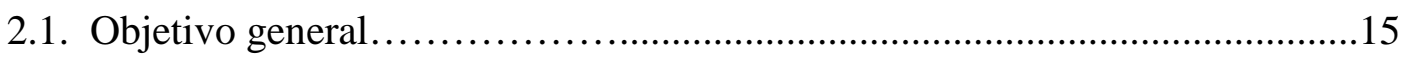

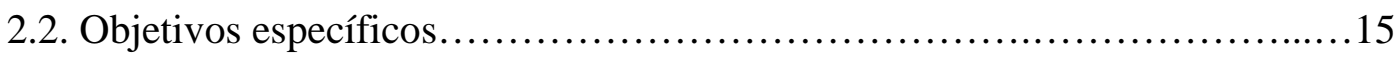

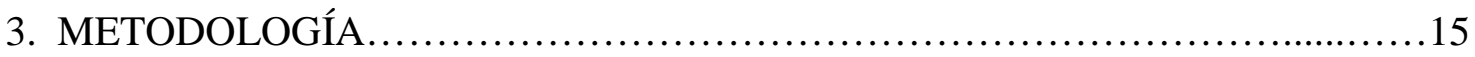

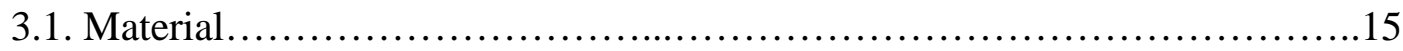

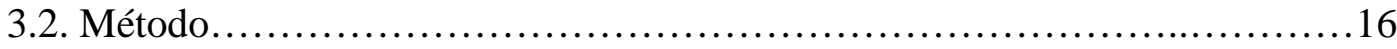

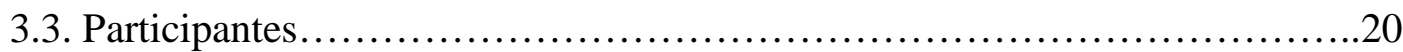

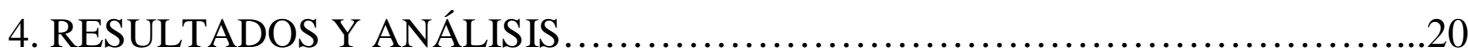

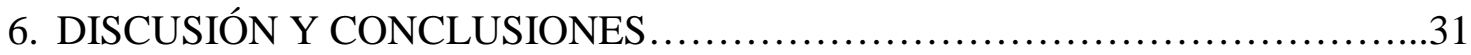

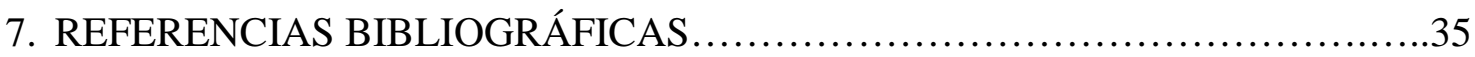

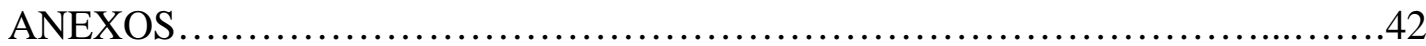

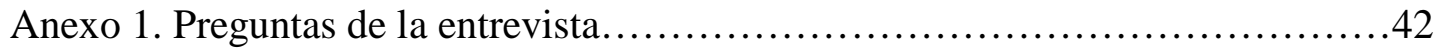

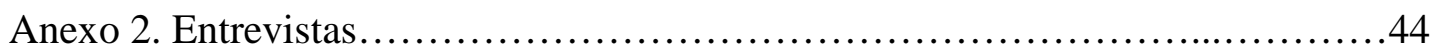

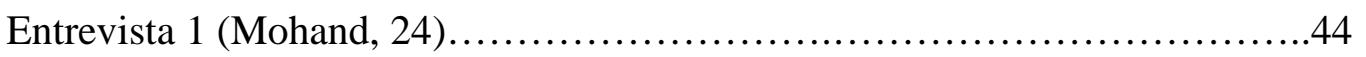

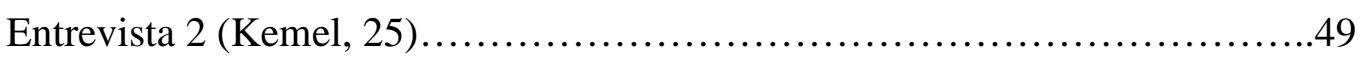

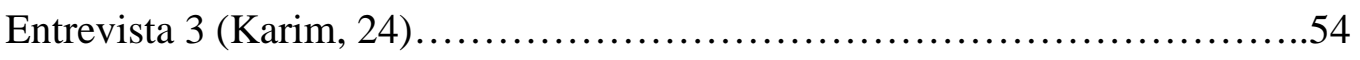

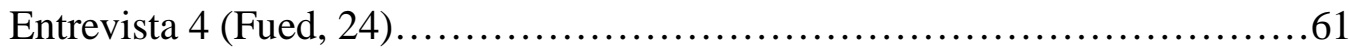

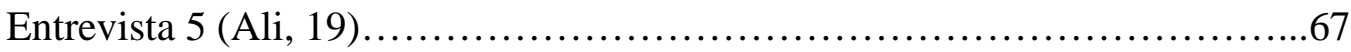

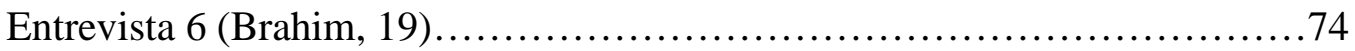

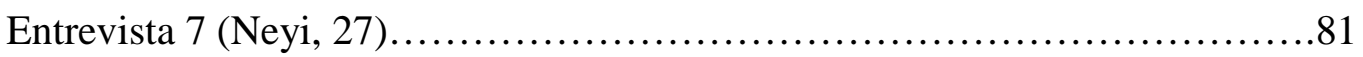

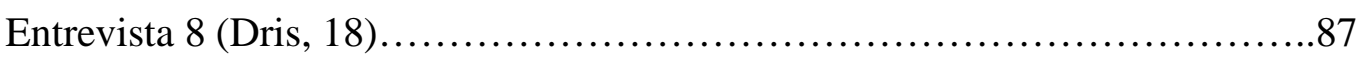

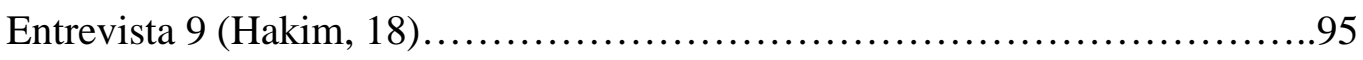

Entrevista 10 (Yaser, 18) .............................................100 


\section{RESUMEN}

Introducción: el número de Menores Extranjeros no Acompañados (MENA) ha aumentado en los últimos años en Melilla. Esta circunstancia ha hecho necesario que la Ciudad busque estrategias de integración de estos menores. La presencia de éstos despiertan numerosas reacciones negativas en la población produciendo una continua sensación de inseguridad en los ciudadanos. Sin embargo, paralelamente a esta realidadexisten menores que han logrado integrarse satisfactoriamente en la sociedad.

Objetivo: conocer la situación de los menores no acompañados que acceden de manera irregular a la ciudad de Melilla valorando los factores que promueven una inserción social exitosa.

Metodología: estudio observacional descriptivo transversal, con una metodología cualitativa. Mediante entrevistassemiestructuradas. Con una muestra de 10 varones, ex menores tutelados de Melilla (18-27 años).

Resultados: la mayoría de los participantes son de Marruecos, mantienen vínculos familiares y presentan un estilo de vida.

Conclusiones:se establecen entre otros factores necesarios para favorecer la integración el seguimiento de las normas de los centros, realización de formación, practicar deporte, crear la figura del tutor, aprendizaje del idioma, creación de una red de contactos, elaboración de objetivos por parte del menor y mantenimiento de la motivación por conseguir los mismos.

PALABRAS CLAVE: Menores de la calle, Menores Extranjeros no Acompañados (MENA), integración, formación, centro de menores. 


\begin{abstract}
Introduction: The number of unaccompanied foreign minors (MENA) has increased in recent years in Melilla. This circumstance makes the City the need to identify integration strategies of these minors. The presence of these despite an important number of negative reactions in the population producing a continual feeling of insecurity among citizens. In addition, parallel to this reality, there are minors that have been able to integrate successfully into society.
\end{abstract}

Study objective: To know the situation of unaccompanied foreing minors whoirregularlyaccessthecity of Melilla byassessingthefactorsthatpromote a successful social insertion.

Methodology: A descriptive cross-sectional observational study with a qualitative methodology. Through semistructure interview. Sample of 10 males, ex-protected minors of Melilla ( age of 18-27)

Main results: The majority of participants are from Morocco, mantein the contact with their families and have a lifestyle.

Conclusions:Are establishedamongotherfactorsnecessarytopromoteintegration, followthe rules of the centers, conduct training, playsports, createthe figure of the tutor, learnthelanguage, create a network of contacts, development of objectivesbytheMinor and maintenance of themotivationtogetthem.

KEYWORDS: Minors of the street, unaccompanied foreign minors, integration, training, centre for unaccompanied minors. 


\section{INTRODUCCIÓN}

En los últimos años la migración ha tenido un gran auge en la población de Melilla. Teniendo en cuenta su situación geográfica, ciudad limítrofe con Marruecos, la hace especialmente vulnerable la accesibilidad a la inmigración.

Según el diario La Vanguardia, 2017, en la actualidad hay más de 500 menores extranjeros no acompañados -MENA- atendidos por la Ciudad Autónoma de Melilla, sin embargo en 1997 no había ninguno. A continuación se exponen las cifras que recoge este diario en la siguiente tabla:

Tabla 1: Datos de inmigración de MENA en Melilla

\begin{tabular}{cc}
\hline AÑO & NÚMERO DE MENA \\
\hline $\mathbf{1 9 9 7}$ & Ningún MENA \\
$\mathbf{1 9 9 8}$ & 2 MENA \\
$\mathbf{1 9 9 9}$ & 56 MENA \\
$\mathbf{2 0 0 0}$ & 11 MENA \\
$\mathbf{2 0 0 4}$ & 165 MENA \\
$\mathbf{2 0 1 1}$ & 257 MENA \\
$\mathbf{2 0 1 5}$ & 383 MENA \\
$\mathbf{2 0 1 6}$ & 505 MENA \\
\hline
\end{tabular}

Tabla de elaboración propia para el resumen de los datos sobre la inmigración de los MENA en Melilla por año.

Según la descripción del Alto Comisionado de las Naciones Unidas para los Refugiados (ACNUR), en 1997 y Fernández Millán, Hamido Mohamed \& Fernández Navas, 2011, se define MENA como:

"Los niños y adolescentes menores de 18 años que se encuentran fuera de su país de origen y están separados de ambos padres o de la persona que por ley o costumbre les tuviera a su cargo. Algunos de estos menores están totalmente solos mientras que otros conviven con otros familiares (Gallego Obieta, Martínez Soler, Ortiz Barahona, Pastor Valdés, Pérez Burrull\& Valero Torrejón, 2006, p. 6)”. 
Según los datos del portal de transparencia de melilla.es, página oficial de Melilla, la Ciudad cuenta con cuatro centros de menores. Uno de ellos es el Centro Asistencial Gota de Leche y en su interior se encuentran ubicados tres pabellones y un centro, todos ellos destinados a menores. A continuación presentamos el tipo de centro y tipo de menores a los que se atiende (Tabla 2):

Tabla 2: Centros de menores en Melilla

\begin{tabular}{|c|c|c|}
\hline NOMBRE & TIPO DE CENTRO & TIPO DE MENORES \\
\hline $\begin{array}{l}\text { Centro de Menores Fuerte } \\
\text { La Purísima }\end{array}$ & Centro de protección & $\begin{array}{ll}\text { Menores extranjeros no } \\
\text { acompañados (MENA) de } \\
12 \text { a } 18 \text { años }\end{array}$ \\
\hline Centro Divina Infantita & Centro de protección & $\begin{array}{l}\text { Menores extranjeras no } \\
\text { acompañadas-niñas. Niñas } \\
\text { que se encuentran en } \\
\text { desamparo familiar }\end{array}$ \\
\hline CEMI Ciudad de Melilla & Centro de reforma & $\begin{array}{l}\text { Menores que se encuentran } \\
\text { sujetos a algún tipo de } \\
\text { medida judicial de } \\
\text { internamiento }\end{array}$ \\
\hline \multicolumn{3}{|c|}{ CENTRO ASISTENCIAL GOTA DE LECHE } \\
\hline Casa cuna & Centro de protección & $\begin{array}{l}\text { Menores de entre } 0 \text { a } 4 \text { años } \\
\text { que se encuentran en } \\
\text { desamparo familiar }\end{array}$ \\
\hline $\begin{array}{l}\text { Pabellón Sor Concepción } \\
\text { Sánchez de niñas }\end{array}$ & Centro de protección & $\begin{array}{l}\text { Menores niñas de entre } 4 \text { a } \\
14 \text { años que se encuentren } \\
\text { en desamparo familiar. } \\
\text { También MENA-niñas }\end{array}$ \\
\hline $\begin{array}{l}\text { Pabellón Sor Concepción } \\
\text { Sánchez de niños }\end{array}$ & Centro de protección & $\begin{array}{l}\text { Menores varones de entre } 4 \\
\text { a } 14 \text { años que se encuentren } \\
\text { en desamparo familiar por } \\
\text { cualquier motivo. También } \\
\text { MENA-niños }\end{array}$ \\
\hline Hermano Eladio Alonso & Centro de protección & MENA entre 14 a 18 años y \\
\hline
\end{tabular}




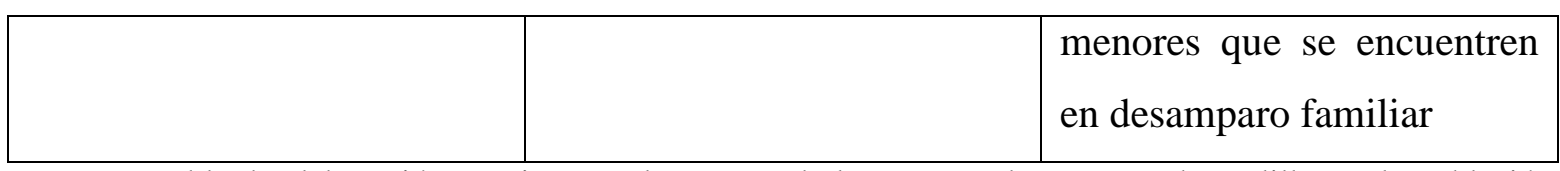

Tabla de elaboración propia para el resumen de los centros de menores de Melilla y a la población que atienden.

Según la Ley Orgánica 1/1996, de 15 de enero, de Protección Jurídica del Menor, de modificación parcial del Código Civil y de la Ley de Enjuiciamiento Civil, en su última modificación de 29 de julio de 2015, la guarda de los menores será asumida por la Entidad Pública, en este caso la Ciudad Autónoma de Melilla, además de la elaboración de un programa individualizado donde se especifican los objetivos a trabajar para la preparación del menor a la vida adulta, favoreciendo su inserción en la sociedad del País de acogida (BOE $\mathrm{n}^{0}$ 15, de 17 de enero de 1996).

Según la Ley Orgánica 8/2000, de 22 de diciembre, de reforma de la Ley Orgánica 4/2000, de 11 de enero, sobre derechos y libertades de los extranjeros en España y su integración, una vez que los menores entran en territorio español tendrán los mismos privilegios que aquellos que tengan documentación dentro del marco del Título I de la Constitución (BOE $\mathrm{n}^{\circ}$ 307, de 23 de diciembre de 2000).

Existe un número elevado de menores que se encuentran fuera del sistema de protección. A estos menores se les está denominando “menores o MENA de la calle”. Esta especificación del nombre, realizada sobre todo por personal que se dedica a este ámbito, se hace para diferenciarlos de aquellos MENAtutelados(Cepero Espinosa \& Herrera Clavero, 2008).

De acuerdo con la información recogida en las entrevistas a menores que se recogen en el estudio de la Asociación Harraga,Melilla es considerada como una ciudad de paso para poder trasladarse a la Península, o incluso a algunas ciudades europeas. Los MENA piensan que en otras ciudades van a tener mayor facilidad para conseguir la documentación y regularizar su situación, pudiendo iniciar una nueva vida (Antúnez Álvarez, Driss Cotilla, García Cotilla \&OlcinaVialplana, 2016).

El hecho de que tomen a Melilla como ciudad de paso, hace que muchos MENA se encuentren viviendo en la calle, debido a que los medios de transporte para trasladarse a la 
Península Ibérica que suelen utilizar con mayor frecuencia, son los barcos que hacen el trayecto hacia la Península. Muchos de estos transportes realizan las travesías en horarios incompatibles con los horarios de los Centros de Protección que se encuentran en la Ciudad. Esto propicia que muchos de estos menores opten por pernoctar en las calles de Melilla y no retornar a los Centros de acogida. Esta circunstancia tiene como consecuencia que en la actualidad haya un número elevado de menores en las calles de Melilla, sin documentación, asistencia médica, educativa y social. Teniendo en cuenta estas circunstancias, si estos aspectos no están cubiertos, sus necesidades básicas tampoco lo están, puesto que no cuentan con ninguna fuente de ingreso para obtener, alimentación y vestimenta, muchos de ellos utilizan métodos poco convencionales para conseguirlo (Antúnez Álvarez et al., 2016).

A pesar de estas circunstancias, desde el Juzgado de menores $\mathrm{n}^{\circ} 1$ de Melilla se afirma en declaraciones a Cablemel TV afirma que, "solo el 10\% de los delitos cometidos por menores en Melilla están efectuados por MENA” (Cablemel, 2016).

\subsection{Características de los MENA}

El perfil de estos menores se sitúa en la etapa de la adolescencia. La Organización Mundial de la Salud (OMS, 2016) define adolescencia como "la etapa que transcurre entre los 11 y 19 años, considerándose dos fases, la adolescencia temprana de 12 a 14 años y la adolescencia tardía de 15 a 19 años”.

Hay distintas definiciones de adolescencia, pero todas coinciden en señalar que es un momento del ciclo vital muy fluctuante para la persona, que en ocasiones se vive de manera drástica, y se deben afrontar los distintos objetivos y cambios, para llegar a la transformación que supone alcanzar la madurez (Gómez-Fraguela, Luengo-Martín, Romero Triñanes, Villar-Torres, Sobral-Fernández, 2006).

De acuerdo con Manzani (2014), los MENA que llegan a los centros de menores de España, en concreto a Melilla, tienen las siguientes características:

- $\quad$ Se encuentran en el rango de edad de 11 a 17 años. 
- La mayoría son varones

- Originarios de Marruecos

Las circunstancias que motivan el movimiento migratorio en los menores, según el estudio de Gallego Obieta et al. (2006):

- Niños que proceden de familias normalizadas y se encuentran dentro del sistema escolar (10\%).

- Niños de familias normalizadas, aunque no cuentan con un nivel socioeconómico alto. No están en situación de abandono (40\%).

- $\quad$ Niños de familias en el umbral de la pobreza con familias no estructuradas (35\%).

- Niños que se encuentran viviendo en la calle en su país de origen (15\%).

Los menores cuentan con distintas circunstancias que propician su migración. Alguno de ellos lo hace para buscar un futuro mejor, otros para escapar de situaciones adversas en su país de procedencia y otros para una reagrupación familiar (Bhabha, 2008).

\subsection{Factores relacionados con la migración de estos menores}

Quiroga, Alonso y Armengol (2005), exponen los hechos que motivan la migración de estos menores. Entre los factores motivadores de estos menores hacia la iniciación del proceso migratorio, se identifican las siguientes;

- Las expectativas en la mejora económica

- La perspectiva de mejor cultural

- La sensación de mejora política

Muchas de estas expectativas incluso son generadas por su propia familia. En casos particulares también la migración se toma como vía de escape ante situaciones adversas familiares y/o estructurales (Fuentes Sánchez, 2014).

Las circunstancias en las que se encuentra cada menor a la hora de iniciar su proceso de migración son diversos; 
- Puede darse desde familias estructuradas

- Familias desestructuradas y que mantengan un nivel socioeconómico bajo

- Familias en riesgo de exclusión social

Existen casos de menores que no han salido nunca del núcleo familiar o personas que ya habían experimentado previamente una situación de inmigración, o bien, que ya lo habían intentado con anterioridad sin éxito. En función de cuál sea el perfil y la motivación del menor que inicia el proceso migratorio, una vez que llegue al país receptor tendrá distinto nivel de motivación para enfrentarse a la situación de adaptación y de reinserción en el país receptor (Manzani\&Arnoso Martínez, 2014).

Tomar la decisión de iniciar un proceso migratorio puede venir motivado por razones económicas, políticas y sociales. En algunas ocasiones la decisión es tomada de manera individual. El propio menor es el que decide partir de su casa hacia otro país, en otros casos es una decisión tomada a nivel familiar. Este viaje se realiza con la idea de poder conseguir documentación, un trabajo y estabilidad económica para obtener una mejora para él y por ende, para su familia (Gabriela Monteros, 2007).

Según Jiménez, antropóloga y miembro del colectivo andaluz Al-Jaima,La migración de menores, es una evolución del tipo de migración que ha estado experimentando el pueblo marroquí a lo largo de estos años, puesto que primero emigraban los padres, después pasaron a emigrar las madres y en la actualidad se produce en mayor medida la migración de los menores de las familias (Jiménez Álvarez, 2011).

\subsection{Fuentes de información de los menores extranjeros no acompañados}

Debido al auge que han tenido los medios de comunicación, existen concepciones erróneas del resultado y experiencia de la migración a otros países. Hay vecinos que emigraron y que vuelven en fechas puntuales a sus casas y país de procedencia. Regresan como personas de éxito, sin embargo, no hacen constar la veracidad de la situación. En la mayoría de los casos en el país receptor se producen situaciones adversas tales como tener 
trabajos precarios, ser beneficiarios de ayudas sociales, se produce una inadaptación de sus hijos al sistema educativo, entre otros circunstancias (Gallego Obieta et al., 2006).

En las entrevistas del estudio Harraga en Melilla 2016, se puede apreciar que varios de los menores comentan que su fuente de información sobre otros casos de migración exitosa previos hacia España u otros países,han sido sobre todo de las redes sociales, como por ejemplo Facebook (Antúnez Álvarez, Driss Cotilla, García Rodríguez, OlcinaVilaplana, 2016).

Sin embargo, también hay numerosas fuentes de información que relatan la tragediade muchos viajes migratorios, los cuales no alcanzan su deseado objetivo, teniendo un final catastrófico para sus protagonistas, terminando con la muerte de muchos de ellos (Khachani, 2004).

\subsection{Factores que dificultan la integración}

Debido al aumento de población MENAque están sufriendo los Centros de protección, como consecuencia del crecimiento constante de la migración de menores, se están produciendo mayores dificultades en el trabajo en estos Centros, el trabajo individual con cada menor(Gimeno Monterde, 2013).

Algunos menores tienen actitudes y comportamientos disociales, que se agravan cuando comienzan a consumir drogas y pueden dar lugar a otras conductas con consecuencias más graves para su integración, como por ejemplo la comisión de hechos delictivos. Sin embargo, parece que las adicciones son fácilmente superadas, una vez estos menores comienzan a llevar una vida estructurada y se alejan de la calle(Sotomayor Morales \& De la Fuente Robles, 2012).

Dentro de los comportamientosdisociales se puede hacer referencia al consumo de drogas. Las más consumidas por este colectivo son las sustancias volátiles, el pegamento, y las sustancias cannabinoides, el hachís. Sin embargo no suele ser habitual el consumo de otras sustancias como la heroína (Cepero Espinosa, Mohamed Mohand\& Herrera Torres, 2016). 
Panchon (citado por Jariot García, Sala Roca, AnauSabatés, 2015, p. 92) afirma que en numerosos estudios han valorado que los menores que inician el proceso de migración no llegan a realizarlo con éxito. Uno de los principales factores implicados para que no se lleve a cabo una integración exitosa sería el bajo nivel académico, abandono escolar, falta de motivación y escaso apoyo social.

Atendiendo a Blancas Avilés\& Belén Jurado (2010), una vez que estos menores llegan a los 18 años se produce una desvinculación del Centro de acogida, encontrándose en la siguiente situación:

- $\quad$ No disponen de soporte social y familiar

- $\quad$ No poseen documentación

- $\quad$ No tienen residencia

- No cuentan con trabajo, ni sustento

- $\quad$ Sufren problemas personales

- Mantienen hábitos no saludables de vida

- Sentimiento de fracaso en su migración

Otra de las dificultades que se pueden encontrar en la integración de estos menores, es que la mayoría de ellos pierde sus referencias familiares, por lo que no cuentan con apoyo familiar(Sinclair, Baker, Wilson, Gibbs, 2005; López, Santos, Bravo, Del Valle, 2013). En muchos de estos casos estos menores se apoyan en la figura del educador, como figura de referencia -referente familiar-, aunque una vez concluye el acogimiento residencial, dada la mayoría de edad, tiene lugar una de las transiciones más difíciles para estos menores ya que, esta figura desaparece o ya no es tan continua como cuando se encuentra dentro del sistema de protección (Bravo, Del Valle, 2003; García, De la Herrán, Imaña, 2007, López, Santos, Del Valle, 2013).

\subsection{Factores que promueven la adecuada integración}

Según González Báez (citado por Fuentes Sánchez, 2014, p. 109) es importante conocer la cultura del menor para establecer una buena relación entre profesional y 
MENA. Esta relación hace posible que se lleve a cabo unafavorable intervención, sobre todo a nivel psicológico. Para crear esta buena relación "se establecen cinco fases:

- Establecimiento de la relación

- Conocimiento del MENA

- Evaluación y establecimiento de objetivos

- Fase de intervención

- Fase de seguimiento”

Uno de los factores que se ha estudiado como indicador de éxito y que favorece la integración en el país receptor, es el periodo que los niños permanecen en los Centros de Protección. Así cuanto mayor es la estancia, mayor es el índice de éxito que tienen los menores en cuanto a su integración, puesto que obtienen mejores resultados en la educación y la inserción laboral (Jariot García, Sala Roca, AnauSabatés, 2015).

Pecora et al. (2006) señalan diversos aspectos importantes que facilitan la inserción del inmigrante, en este caso del menor. Se especifica la importancia de poder trabajar en alguna ocasión, mantenerse constante en la vida del Centro de acogida, al igual que participar activamente en todas las propuestas educativas del Centro, además de poder realizar alguna formación prelaboralasí como mantener una buena conducta.

Una vez concluye la vida de estos menores en el sistema de protección, pasan a iniciar una transición a la vida adulta, teniendo que adaptarse a nuevos roles y situaciones, para ello se han tenido que preparar durante los años transcurridos en el sistema de protección, para poder obtener una integración positiva. Este proceso tiene más probabilidades de ser exitoso si se completan los estudios, si tienen la posibilidad de ser independientes a nivel laboral y de mantener relaciones maduras (López, Santos, Bravo \& Del Valle, 2013).

\subsection{Justificación}

El interés por estudiar en esta temática surgeal observar la creciente presencia de menores de origen magrebíen Melilla. Éstosacceden en la ciudad de manera irregular, 
vagando por las calles, practicando la mendicidad y viviendo en condiciones infrahumanas. Estos menores se encuentran fuera del sistema de protección de la Ciudad Autónoma. Una parte de ellos accede a ingresar en los Centros de acogida, en los cuáles se les brinda la oportunidad de salir de esta penosa situación. Las particularidades de estos menoresdespiertan el interés por profundizar acerca delos factores determinantes que se encuentran en la base de este problema, de carácter política, social y moral así como, indagar acerca delos factores que pueden favorecerla inserción social de cara a mejorar su calidad de vida.

\section{OBJETIVOS}

\subsection{Objetivo General}

Conocer la situación de los menores no acompañados que acceden de manera irregular a la ciudad de Melilla valorando los factores que promueven una inserción social exitosa.

\subsection{Objetivos Específicos}

- Describir el perfil psicosocial del menor inmigrante.

- Conocer la motivación que les impulsa a emigrar.

- Valorar las situaciones que perjudican y favorecen la reinserción de los MENA.

\section{METODOLOGÍA}

\subsection{Material}

Se ha realizado un estudio observacional descriptivo transversal. Se ha optado por una metodología cualitativa para realizar un acercamiento más directo de la realidad.

Se ha utilizado una entrevista semiestructurada (Anexo 1), con preguntas abiertas, en las que el entrevistado tiene mayor autonomía para poder contestar y argumentar su respuesta. 
La entrevista está compuesta inicialmente 27 preguntas, aunque al ser una entrevista semiestructurada, en algunos casos se ha formulado alguna pregunta adicional, reconduciendo así el relato de los participantes.

Son nueve las dimensiones que se establecenen esta entrevista ad-hoc. Estas dimensiones están estipuladas previamente a la realización de la entrevista a los participantes. Las dimensiones son:

- Procedencia

- Vínculos familiares

- Nivel socioeconómico

- Motivo del proceso migratorio

- Consumo de drogas

- Desarrollo del proceso migratorio

- Vida del Centro en Melilla

- Formación y preparación para la vida adulta

- Salida del Centro

\subsection{Método}

Para facilitar la recogida de datos se ha optado por la grabación de la entrevista, previo permiso del entrevistado. De esta manera se han podido utilizar técnicas muy útiles como de escucha activa, el contacto visual, el mantenimiento de la atención, el parafraseo, lo que ha fomentado la creación de un clima de confianza que ha fomentado que el entrevistadoaporte más información relevante para el presente estudio.

Previamente a la realización de la entrevista se ha explicado a cada uno de los sujetos la finalidad de la entrevista, además se les ha pedido que firmen el consentimiento informado para la grabación de la entrevista y su posterior utilización para el presente estudio. Para mantener el anonimato de los entrevistados se han realizado las entrevistas de manera individual. 
Las entrevistas han sido realizadas entre el mes de mayo y junio del 2017. Han tenido una duración aproximada, según los relatos de los entrevistados, de entre quince minutos y media hora.

Para el análisis de los datos se ha utilizado el análisis cualitativo, a través de la codificación de la entrevista, para facilitar el manejo de la información aportada, según la transcripción de cada una de las entrevistas (Anexo 2).

La codificación se realizó de manera deductiva en base a las preguntas planteadas en la entrevista. Tras la realización de las entrevistas,se planteó la codificación de modo inductivo, teniendo en cuenta las respuestas de los participantes. A continuación se presenta la codificación y preguntas que se encuentran dentro de cada código:

\section{PROCEDENCIA}

- Pregunta 1: ¿De dónde eres?

\section{VÍNCULOSY RELACIONES FAMILIARES}

- Pregunta 2: ¿Con quién vivías en casa?

o Hermanos

o Padre/madre

- Pregunta 4: ¿Te encontrabas bien en casa? ¿Cómo era la relación con tus padres y con tus hermanos (en el caso de que los tuviera)? (Tenías problemas en casa).

- Pregunta 5: ¿Había una buena comunicación familiar, entre tú y tus padres? ¿Y entre tus padres, cómo era la relación? (violencia de género, violencia filioparental)?

- Pregunta 24: ¿Tienes contacto con tu familia?

- Pregunta 26: ¿Te gustaría volver a tu casa de nuevo?

\section{EDAD DE SEPARACIÓN DE LA FAMILIA}

- Pregunta 9: ¿Cuándo llegaste a Melilla? 


\section{NIVEL SOCIOECONÓMICO DE LA FAMILIA DE ORIGEN}

- Pregunta 3: ¿Crees que teníais todo lo necesario para vivir bien?, ¿Crees que era necesario que entrara más dinero en tu casa?

a. Describe tu casa, cuántas habitaciones tenía, decoración...

b. ¿A qué se dedica tu padre/madre?

\section{MOTIVO DE LA INMIGRACIÓN A MELILLA}

6. Pregunta 7: ¿Por qué te decidiste venir a Melilla?

\section{ORGANIZACIÓN DE LA INMIGRACIÓN}

8. Pregunta 8: ¿Cómo organizaste tu viaje?

a. Contacto con alguien

b. Dinero

c. Algún tipo de trámite previo

9. Pregunta 9: ¿Cuándo llegaste a Melilla?

10. Pregunta 10: Cuando llegas a Melilla ¿qué es lo primero que hiciste?

11. Pregunta 11: ¿Conocías a alguien previamente?

12. Pregunta 12: ¿Cómo llegas al Centro?

\section{ACOGIDA DE MELILLA}

- Pregunta 13: ¿Cómo era tu vida en el Centro?. Cuéntame un día allí

14. Pregunta 14: ¿Qué oportunidades te dieron en el Centro?

15. Pregunta 18: ¿Qué cambiarías de tu vida en el Centro?

- Pregunta 21: ¿Piensas que todos los niños tenéis las mismas oportunidades?

16. Pregunta 22: ¿Qué piensas de otros menores que han tenido las mismas oportunidades que tú, pero no están trabajando como tú?

\section{CONSUMO DE DROGAS}

18. Pregunta 6: En tu familia, ¿¿había algún tipo de consumo (antecedente) de alguna sustancias tóxica?

19. Pregunta 17: Una vez que llegas a Melilla, ¿Has consumido algún tipo de sustancias tóxicas? 


\section{FORMACIÓN Y PREPARACIÓN PARA CONSEGUIR LA AUTONOMÍA}

21. Pregunta 15: ¿Hiciste algún curso de formación?

22. Pregunta 16: ¿Conocías el idioma? ¿cómo lo aprendiste?

23. Pregunta 19: ¿Cómo conseguiste trabajo?

\section{FIN DE LA TUTELA DE LOS CENTROS Y SALIDA A LOS “18 AÑOS”}

25. Pregunta 20: ¿Dónde viviste una vez que cumpliste la mayoría de edad?

26. Pregunta 23: ¿Qué consideras que ha hecho que tengas una buena inserción a diferencia de otras personas que no lo consiguen?

27. Pregunta 25: ¿Cómo te sientes en Melilla? (sentimiento de pertenencia)

28. Pregunta 27: ¿Cuáles son tus objetivos? ¿qué quieres conseguir en el futuro?

\section{CONSEJOSA LOS NIÑOS DE LA CALLE}

30. Pregunta 28: ¿Qué le dirías a los niños que deciden quedarse en la calle?

31. Pregunta 29: ¿Por qué crees que los niños se quedan en la calle y no van al Centro?.

\section{VÍNCULO FAMILIAR ACTUAL}

33. Pregunta 24: ¿Tienes contacto con tu familia?

\section{DE MENA A CABEZA DE FAMILIA}

35. Pregunta 3: ¿Crees que teníais todo lo necesario para vivir bien?, ¿Crees que era necesario que entrara más dinero en tu casa?

a. Describe tu casa, cuántas habitaciones tenía, decoración...

b. ¿A qué se dedica tu padre/madre?

36. MIGRACIÓN FAMILIAR

37. Pregunta 11: ¿Conocías a alguien previamente? 


\subsection{Participantes}

Los participantes han sido seleccionados mediante un muestreo no probabilístico de tipo intencional.

El investigador tenía conocimiento previo de alguno de los sujetos entrevistados ya que, durante un periodo de su vida laboral estuvo trabajando en el Centro de protección "Fuerte La Purísima”, aspecto que ha facilitado el mantenimiento de la relación con algunas personas que en la actualidad están integradas.

A través de los chicos que se conocían previamente, se ha podido ampliar la muestra hasta 10 sujetos. Ellos mismos han sido el medio para poder contactar con otros chicos integrados.

Los criterios de inclusiónpara la participación en este estudio han sido los siguientes:

38. Sujetos mayores de 18 años que hayan sido menores no acompañados ingresados dentro del sistema de protección de Melilla.

39. Sujetos que en la actualidad se encuentren en situación activa a nivel laboral, o en su defecto, que tengan establecido el precontrato para ello.

Los participantes en este estudio han sido 10 sujetos, todos ellos son ex menores tutelados de distintos Centros de la Ciudad Autónoma, Fuerte La Purísima y Hermano Eladio Alonso -Gota de Leche-. Tienen edades comprendidas entre 18 y 27 años.

\section{RESULTADOS Y ANÁLISIS}

\section{PROCEDENCIA}

En la mayoría de los casos, los entrevistados provienen de la zona Sur de Marruecos. Sólo un participante es de la zona Norte, cerca de Melilla,otro de la zona Suroeste y uno del Sur de África. 
"Yo soy de Guasasat, la garganta del Todrah. Muy lejos 1.200 km más o menos, 11 horas casi” (Kemel, 25).

"Soy de Oujda" (Fued, 24).

“Soy de Guinea Conakry” (Dris, 18).

“Soy nacido en Nador” (Hakim, 18).

\section{VÍNCULOS Y RELACIONES FAMILIARES}

La mayor parte de la muestra, cinco participantes, refiere vivir con su padre, madre y hermanos. Comentan ser cuatro o más de cuatro hermanos en total; solo en un caso verbaliza tener dos hermanos.

“Antes de venir a Melilla vivía, con mi familia, con mis padres y mis hermanos. Somos 6 hermanos y dos hermanas. Con mi madre y mi padre” (Karim, 24).

Solo un caso vive solo con su madre, previo divorcio del matrimonio, y sus hermanos, que este apartado vuelve a coincidir que son cuatro hermanos con los participantes anteriores.

"Vivía en casa con mi madre, mi dos hermanas y mi hermano.Mis padres se divorciaron y se fue de casa. Yo era muy pequeño, unos 10 u 11 años, me acuerdo de poco, pero sí recuerdo alguna pelea” (Fued, 24).

El resto de participantes verbaliza vivir con parte de su familia extensa, haciéndose cargo de ellos en la mayoría de los casos sus abuelos, aunque también vivían más familiares dentro de estos núcleos, como tíos y algún hermano, según los relatos de los participantes. A pesar de vivir más personas con distinto grado de parentesco, especifican que sus abuelos son sus referentes familiares. Sólo un caso comenta vivir en casa de su tía, siendo ésta su referente familiar.

"Vivía con mis abuelas. Ellas vivían en el mismo edificio, una en el primero y la otra en el segundo y yo estaba entre las dos casas.Mis padres se separaron cuando yo tenía 4 años, mi padre se fue a Mekness y mi madre se fue a Tánger a trabajar y yo me quedé con mis abuelas. Soy hijo único. En casa de mi abuela materna estaban mis tíos, una de mis tías tenía mi edad, así que crecimos como hermanos. Eran tres tías y tres tíos” (Neyi, 27). 
"Vivía con mi tía. Mi madre falleció. Cuando mi madre falleció mi padre se fue a otro sitio. Tengo cinco hermanos, pero una vez que fallece mi madre todos nos separamos. Yo soy el más pequeño" (Yaser, 18).

En la mayoría de los casos había una buena relación entre todos los miembros que componían la unidad familiar. La comunicación cordial, aunque en ocasiones les regañaran como método educativo, debido a que contaban con una corta edad. Sólo dos casos, de entre los participantes entrevistados, especifican que la comunicación en sus familias era escasa, estableciendo una diferencia en las relaciones familiares entre Marruecos y España. Argumentan que los estilos educativos en Marruecos distan mucho de los que han vivido en España, de modo que en las familias no dedicaban momentos a contarse cómo habían pasado el día o hechos sucedido dentro de su jornada diaria. Además, en uno de los casos el participante especifica que la relación con su madre no era buena, ya que le recriminaba constantemente su conducta de una manera que a él le incomodaba, hecho que motivaba conflictos familiares.

"Sí la verdad que sí, estaba muy agusto. Primero en Mekiness que también hacía judo y luego en Nador, que seguí estudiando y jugando al fútbol, lo que pasa es que en Marruecos no te puedes apuntar a un equipo” (Brahim, 19).

“Con mi padre tenía muy buena relación, él me quería mucho. Con quién me llevaba mal era con mi madre. Entiendo que ella quería que siguiera el buen camino, y yo antes de terminar el colegio, antes de salir de mi país, me portaba muy mal y mi madre no quería eso para mí y me pegaba. A veces me pegaba, me chillaba o me tiraba la chancla, o algo así y a mí no me gustaba eso” (Dris, 18).

En cuanto al contacto con la familia, todos comentan que mentienen contacto fluido y regular, aunque en la mayoría de los casos, después de llegar a Melilla tardaron unos meses en tener los medios, económicos y tecnológicos, para ponerse en contacto con ellos, una vez que lo consiguieron ya no han cortado con ellos la comunicación.

“Sí, tengo contacto con mi abuela. Cuando llegué a Melilla no la llamé, porque estaba en la calle. Cuando entré al Centro, un amigo tenía un móvil y la llamé” (Ali, 19). 
Al preguntar a los participantes por la opción de volver a su país de origen para poder hacer allí su vida, todos coinciden en dar una negativa como respuesta, argumentando que se han criado aquí, que España le ofrece mayores oportunidades tanto de trabajo como en su vida personal. En algunos casos especifican que no les importaría vivir allí cuando fueran mayores y tuvieran dinero, concretando que en su jubilación.

"Me gustaría volver cuando la tarjeta de crédito esté llena, para retirarme. Para la jubilación.De momento está bien solo para las vacaciones. A mi me gusta más Melilla, yo soy de aquí y ahora sería muy difícil cambiar mi forma de vida” (Karim, 24).

\section{EDAD DE SEPARACIÓN DE LA FAMILIA}

Se puede concentrar la edad a la que se inicia la migración en dos grupos, uno antes de los 10 años y otro después. Hay tres jóvenes que inician este proceso a unas edades muy tempranas, de los 5 a los 7 años, coincidiendo con aquellos que son acompañados por sus familiares en este proceso. Siete lo hacen de los 12 a los 16 años. De este último grupo sólo uno viene a Melilla con 16 años.

“Entré a Melilla con 6 años. Llego en el 2005” (Hakim, 18).

\section{NIVEL SOCIOECONÓMICO DE LA FAMILIA DE ORIGEN}

En cuanto al nivel socioeconómico, 6 de los 10 participantes, comentan que no tienen ninguna dificultad económica. En la mayoría de los casos no tenían economía para caprichos innecesarios o lujos, pero tenían cubiertas sus necesidades básicas. Sin embargo, 4 de ellos expresan su de aumentar la economía de su hogar, verbalizando ser muy humildes, encontrando muchas dificultades para pagar facturas, ropa u otras cuestiones.

En la mayoría de los casos especifican queno veían que tuvieran futuro en su país y su casa, en cuanto a la posibilidad de encontrarun trabajo y cursar estudios. 
"Sí teníamos todo lo necesario para vivir, lo que pasa que en Marruecos tienes para vivir un $50 \%$. En mi casa no ha faltado de nada. Aunque yo soy una persona que me di cuenta que en el colegio, en los estudios, no iba a llegar lejos, así que decidir emigrar” (Karim, 24).

“Teníamos comida, teníamos ropa, pero no teníamos futuro, yo porque era pobre, no podía estudiar, si estudiaba ¿quién iba a trabajar para mí?, mi abuela estaba un poco vieja y aunque se buscaba la vida, vendiendo la fruta y verdura que recolectaba, también teníamos una vaca, pero era yo el que tenía que trabajar para mi abuela y mi hermano pequeño” (Ali, 19).

\section{MOTIVO DE LA INMIGRACIÓN A MELILLA}

Todos los entrevistados coinciden en señalar que el motivo por el que iniciaron su proceso migratorio fue para poder tener un futuro mejor. Vinieron en busca de más y mejores oportunidades, tanto a nivel formativo, como a nivel laboral. A pesar de no estar pasando adversidades en todos los casos, eran conscientes de las posibilidades de futuro que les ofrecía este país.

"Mejorar uno, cambiar de vida, buscar un trabajo. aquí mejor, más cosas, más oportunidades” (Mohand, 24).

A lo largo de la entrevista, los participantes fueron relatando cómo realizaron su viaje, cómo lo planificaron y cuál era su destino, una vez salieron de su país de origen. De todos los entrevistados, ocho de ellos tenían como destino Melilla. Dos comentan que no tenían como destino Melilla. Uno de ellos en concreto, lo que deseaba era salir de su País y no supo de Melilla hasta que llegó a Rabat y otro no sabía de la existencia de Melilla y sus Centros de acogida hasta llegar a Nador, que fue su primer destino.

"Poder tener una vida mejor. Nadie me contó nada sobre Melilla, mi idea inicial era ir a Nador a trabajar. Ahí empezó todo.Una vez que llegué a Nador conocí gente que me aconsejó venir a Melilla y les hice caso” (Kemel, 25). 


\section{ORGANIZACIÓN DE LA INMIGRACIÓN}

En lo que respecta a la organización previa de la inmigarción la mitad de la muestra, 5 participantes, habían contado con sus familiares para la realización y organización de su proceso migratorio, incluso en algunos de los casos fueronlos propios padres quiénes los trajeron y ayudan a pasar por la frontera. También se da el caso, de los otros 5 entrevistados, que no cuentan con nadie, realizando el viaje migratorio de manera totalmente autónoma. Esto no significa que no estuviera orquestado con anterioridad, puesto que en algunos casos se pusieron a trabajar con antelación para poder ahorrar y hacer frente a los gastos del viaje.

“No organizo nada, puesto que la decisión de venirme no fue mía. Me fui a casa de una tía
en Marruecos y ella me trae con unos 7 años a casa de una tía aquí en Melilla” (Yaser, 18).

“Me levanté por la mañana, cogí unos $600 €$ que tenía guardado de mi padre y me fui del país sin avisar a nadie, ni contar con nadie” (Dris, 18).

No se describe un medio de transporte por excelencia para llegar hasta Melilla. Está condicionado por la distancia del trayecto. Concretamente 4 de ellos, fueron acompañados por sus familiares, padres, tíos o hermanos. Tres utilizan el autobús para venir, solo uno de ellos utiliza como medio de transporte el taxi y otro utiliza varios medios de locomoción, debido a la lejanía de su país de procedencia.

\footnotetext{
"Me tiré un verano entero trabajando en un taller de mecánico de ruedas, y así me hice el pasaporte para poder pasar a Melilla. Entré por la frontera con un hombre que yo no conocía y que se hizo pasar por mi tío. Yo en realidad no entendí nada. De Oujda a Nador vine en taxi, tardamos unas dos horas y poco” (Fued, 24).
}

A continuación se relacionan las modalidades de entrada y el número de participantes que usaron cada medio:

- Acompañados por sus familiares: 3

- Por la frontera de Barrio Chino ayudando a transportar la compra: 4

- Por la frontera de Beni Enzar, aprovechando la ausencia momentánea de vigilanciade la Guardia Civil y Policía Nacional: 1 
- $\quad$ Mediante las mafias de trata de personas, previo pago: 2

“Crucé la frontera por Barrio Chino, echándole una mano a una mujer con las bolsas y ya no volví a entrar” (Mohand, 24).

"Yo crucé, pagando a un hombre para poder pasar en el maletero de un coche. Lo hice así porque era muy pequeño y no tenía la fuerza necesaria para saltar la valla. Cuando pasé pillaron al conductor, y éste huyó y yo me quedé allí, no quería salir del maletero, hasta que la Guardia Civil me convenció” (Dris, 18).

Todos los entrevistados exceptuando un solo caso llegaron a los Centros de protección mediante la Policía Local. Gran parte de la muestra fueron ellos los que se acercaron a comisaría con el fin de poder llegar al Centro de acogida, sin embargo hay dos casos, uno por no llevar documentación y estar en la calle y otro por haber cometido un delito, es la propia Policía quién los encuentra en la calle y lolleva al Centro. Hay una excepción, y es que una familia se dirigió directamente a la Consejería de Bienestar Social, según verbaliza el entrevistado ingresando en el Centro de esa manera.

\footnotetext{
"Mi tía me llevó a Consejería, para decirle que no se podía hacer cargo de mí. Me llevaron directamente a La Purísima, a la espera de que se quedara un plaza libre en La Gota de Leche” (Hakim, 18 años).
}

\section{ACOGIDA DE MELILLA}

A lo largo de las entrevistas todos expresan su bienestar en el Centro en el que estuvieron tutelados, ya fuera La Gota de Leche o Fuerte La Purísima. Han recalcado que ha sido un difícil proceso de adaptación, pero que lo superaron de manera satisfactoria. Además, de forma autónoma todos han agradecido al Centro y a su personal, en muchos casos a personas concretas, su atención y dedicación y han especificado que no cambiarían nada, con dos salvedades, en un caso ampliarían el horario de comida y en otro mandarían a los niños que "no se portan bien ni siguen las normas” a otros Centros especializados. Sólo uno de ellos se ha mostrado crítico con uno de los Centros, en concreto con Fuerte La Purísima, especialmente por las pautas educativas del mismo en comparación con el Centro Gota de Leche. 
“Nunca tuve ningún problema en el Centro, todo muy bien”(Brahim, 19).

"Los dos años del Centro La Purísima estuve muy mal. Me escapaba continuamente, dormía en la calle, mi familia no sabía nada de mí. Me iba a la calle porque ese Centro no está bien. Es un Centro que no es como La Gota de Leche, que tenga unas normas que se lleven a raja tabla, cada uno va a su bola. La educación no es buena, no se usa la comunicación como en La Gota de Leche” (Hakim, 18).

Es unánime la idea de que todos los menores que vienen a Melilla tienen las mismas oportunidades y opinan que permanecer en la calle es una opción y no una obligación. Todos los entrevistados enumeran distintos comportamientos importantes que tienen que llevar a cabo para poder conseguir la documentación y una inserción en Melilla y por ende, en España. Son críticos con los menores que se encuentran en la calle y piensan que lo hacen por decisión propia y ellos son los únicos responsables de su situación.

“Sí, todos tenemos las mismas oportunidades. El Centro es igual para todos” (Kemel, 25).

"Para poder conseguir algo tienes que sufrir por ello, tienes que trabajar por ello. Tengo muchos amigos que han conseguido la documentación y ahora están fuera de Melilla” (Ali, 19).

\section{CONSUMO DE DROGAS}

Para este código se han tenido en cuenta tanto el consumo de la familia, para conocer los antecedentes, como el propio consumo del entrevistado.

Según las respuestas dadas, 7 de los 10 participantes, no tenían ningún familiar consumidor de ningún tipo de sustancia tóxica y ellos tampoco han sido consumidores siendo menores. En la actualidad, siendo mayores de edad, algunos de ellos refieren beber alcohol ocasionalmente cuando sale con sus amigos. 2 de ellos, tienen familiares que sí son consumidores de tabaco, hachís y alcohol. Uno de ellos comenta que su madre era alcohólica; sin embargo ninguno de ellos dice ser consumidor de ningún tipo de droga actualmente. Sólo una persona tiene familia que ha consumido tabaco y hachís, y siendo 
menor ha probado tanto el hachís, como el pegamento, aunque en la actualidad no es consumidor de ningún tipo de droga.

"Mi padre sí era consumidor de tabaco y hachís. Aunque una vez que enferma y le operan, dejó el hachís. Hoy día sigue fumando tabaco, aunque en pocas cantidades. Estando en el Centro si probé el hachís y el pegamento en un tiempo. No mantuve el consumo, solo fue por probar. Estando en el Centro con los niños es difícil no probar ningún tipo de sustancia” (Fued, 24).

\section{FORMACIÓN Y PREPARACION PARA CONSEGUIR LA AUTONOMÍA}

Son numerosas las oportunidades que les ofreció el Centro, según los relatos de los entrevistados. El aprendizaje del castellano desde el inicio, puesto que ninguno tenía conocimiento de la lengua a su llegada a Melilla. La formación educativa y profesional, ya que son diversos los cursos acreditados que han hecho todos los participantes de este estudio, además de haber obtenido el Graduado en Educación Secundaria Obligatoria en algunos de los casos. Estos cursos de formación les han servido para poder tener un primer contacto con el mundo laboral gracias a las prácticas de empresa, actividad que algunos han aprovechado para conseguir un trabajo.

"El Centro me ha dado mucho. Lo primero fue conocer el idioma, cuando llegué no sabía decir ni “hola” y allí nos enseñaron el idioma” (Kemel, 25).

"El primer trabajo fue porque hice las prácticas de la escuela de hostelería y allí me quedé trabajando" (Fued, 24).

"Me saqué la ESO y ahora quiero seguir estudiando porque el fútbol es una vida corta, hasta los 35 o los 36 años” (Brahim, 19).

\section{FIN DE LA TUTELA DE LOS CENTROS Y SALIDA A LOS “18 AÑOS”}

Todos los entrevistados coinciden en señalarque se encuentran muy a gusto en Melilla, incluso especificando que se han criado aquí y se identifican más con Melilla y España que con Marruecos, mostrando así un importante desarraigo respecto a su País de origen.Sólo tres de los participantes consideran la idea de ir a la Península a seguir con su 
vida, trabajando y formar fuera una familia. Los demás no muestran interés por salir de Melilla para vivir en otra Ciudad.

"Me siento como en casa, me falta el calor de mi madre, pero que se le va a hacer" (Karim, 24).

La vida laboral es un aspecto importante para ellos, porque sin un trabajo o precontrato no tienen la oportunidad de gestionar la documentación. Son diversas los medios por los que han conseguido el contrato. Un grupo lo consiguió a través de las prácticas de empresa de un curso de formación. Otro grupo por su red de conocidos, dos de los participantes entregando el currículo y siendo persistentes en la entrega y visitas a algunas empresas y otro fue porque jugando al fútbol con un equipo amateur lo ficharon.

“El primer trabajo fue porque hice las prácticas de la escuela de hostelería y allí me quedé trabajando" (Fuad, 24).

En un aspecto en el que son coincidentes todoslos participantes, es que todos ellos han luchado por estar donde están. La diferencia entre ellos y aquellos que no han conseguido la documentación e insertarse, ha sido que ellos, cada uno en su Centro, ha mantenido un buen seguimiento de las normas, no ha provocado ni participado en conflictos, ha colaborado en la vida del Centro, se ha formado, ha cumplido los horarios y sobre todo, que han tenido muchas ganas de salir hacia delante.

"La diferencia ha sido que me he adaptado a las normas, me he levantado temprano he hecho cursos y me he esforzado mucho en los cursos. No me he quedado durmiendo y dando vueltas por las calles, he aprovechado el tiempo, he buscado mi suerte” (Kemel, 25).

\section{CONSEJOS A LOS NIÑOS DE LA CALLE}

Todos los participantes responden de manera similar a estas cuestiones, destacando que recomiendan a estos menores acudir a los centros de protección, seguir las normas y aprovechar las oportunidades de formación y educación que se les ofrece desde los mismos. Especificando que todos son iguales en los Centros, por lo que si ellos han conseguido sus objetivos todos pueden, pero hay que trabajar y esforzarse por ello. Son 
coincidentes en la opinión de que los menores de la calle tienen la idea férrea, pero errónea, de cruzar a la Península pensando que allí van a tener más oportunidades que aquí.

"Mira para ganar dinero hay que trabajar. Pues para conseguir los papeles también. Si no haces cursos, robas, fumas, te peleas, es normal que no consigas papeles. He hablado con un amigo mío que está en la calle y él me dice que tenía liada la cabeza, que estaba tonto y ahora llora; yo le digo que tenía que haber llorado antes, ahora no sirve, ahora es mayor" (Ali,19).

\section{VÍNCULO FAMILIAR ACTUAL}

La familia para ellos es muy importante, de hecho ha sido el motivo de algunos viajes a Melilla. Mantienen contacto con ellos de manera regular, a través de llamadas telefónicas, redes sociales e incluso visitas en vacaciones. En algunos casos el contacto con la familia después del trayecto hacia Melilla se demoró, debido que necesitaron un tiempo para conseguir medios para ponerse en contacto con ellos. En general,la forma más utilizada ha sido las llamadas telefónicas, sobre todo siendo menores de edad, porque a estas edades no pueden salir de Melilla, por lo que las visitas se hacen imposibles hasta cumplir la mayoría de edad.

"Sí, hablo a menudo con ellos. Al principio estuve tres meses sin hablar con ellos. Pasado ese tiempo, los llamé y les comenté que me encontraba bien” (Dris, 18).

\section{DE MENA A CABEZA DE FAMILIA}

A lo largo de las entrevistas y sin ser una pregunta hecha de manera explícita, algunos participantes, en concreto 4 de los 10 participantes, especificaron que ahora que ellos se encuentran en una buen situación económica, ayudan a sus familias mandándoles dinero o haciendo otras cosas por ellos, como por ejemplo una casa, dependiendo de las necesidades de cada caso. Todos coincidían en que la idea de venir aquí había sido por mejorar su vida y buscarse un futuro, pero esa idea no les implica sólo a ellos, también se extiende a su familia. 
“Ahora he hecho una casa, una casa que tiene dos pisos. Es mía pero vive mi familia allí.La casa que te he descrito antes era la antigua de barro, ahora con un poquito de esfuerzo tenemos una casa mejor. La casa de ahora tiene abajo tres habitaciones, un salón, la cocina y un cuarto de baño y arriba tiene una salita dos cuartos y arriba la azotea, aunque allí he hecho dos habitaciones también” (Kemel, 25).

\section{MIGRACIÓN FAMILIAR}

En el transcurso de las entrevistas, la mayoría de los participantes, al menos 7 de los 10 totales, refirieron que algún familiar, ya fuera hermano o hermana o primos, realizaron antes o después que ellos, el mismo proceso de migración que él había realizado. En algunos casos estos parientes sirvieron de guía y de ayuda para realizar su entrada en Melilla y en otros casos los entrevistados fueron quienes abrieron el camino para sus familiares.

\footnotetext{
“Mi hermana mayor ya estaba aquí en Melilla. Ella vino con 14 años. Vino porque una tía mía vivía aquí. Ya a los 18 años se casó en Melilla y ya se quedó aquí.Antes de que viniera mi hermana, teníamos una tía y un primo que habían venido antes a Melilla, aunque no vinieron a través del Centro” (Hakim, 18).
}

\section{DISCUSIÓN Y CONCLUSIONES}

Siendo la migración de Menores Extranjeros no Acompañados un fenómeno en aumento, nos encontramos con la necesidad de dar respuestas a esta población, respuestas que sean eficaces para la integración de este colectivo.

Como ya se ha comentado anteriormente uno de los aspectos significativos para favorecer la integración, es no causar baja en los Centros de acogida, al igual que la participación en todas las actividades (López, Santos, Del Valle, 2013). Esta idea ha sido muy recalcada por todos los participantes, permanecer constantemente en el Centro hasta cumplir la mayoría de edad. Además, los entrevistados valoranque llegar cuanto más pequeños mejor, de cara a tener más posibilidades de conseguir la documentación. Sin embargo, entre los entrevistados hay una persona que llegó con 16 años a Melilla y solo 
pasó año y medio en el centro de protección. Este hecho constata que este factor es importante pero no determinante por sí solo.

Pecora et al. (2006) señalan diversos aspectos relevantes que facilitan la inserción del inmigrante, entre ellos se especifica la formación. Esto ha sido muy destacado por todos los participantes. Según las entrevistas, todoshan realizado cursos, algunos dentro de la educación reglada pudiendo obtener el título de Graduado en Educación Secundaria Obligatoria, y otros en la no reglada haciendo cursos de formación ocupacional que, además en algunas situaciones les ha ayudado para conseguir un trabajo gracias a las prácticas laborales. Se resalta el aprendizaje del idioma. Ninguno de ellos conocía el idioma a su llegada a Melilla. Gracias a su paso por el Centro de Protección lo han adquirido. Este aspecto es definitivo para poder integrarse adecuadamente. En un caso en concreto se ha referido a la ausencia de cursos de formación, sin embargo la integración se ha conseguido mediante la práctica de deporte, pautas importantes para el mantenimiento de hábitos de vida saludables. Muchos de los participantes realizan prácticas deportivas con frecuencia.

Lafuente (2010), en su desarrollo de características de los MENA, hace hincapié en que muchos ya cuentan con alguna experiencia laboral. Esta circunstancia en algunos casos ha dotado a los participantes de las habilidades socialesnecesarias para poder establecer una red de contactos. Estas han sido encauzadas por los Centros. Estas redes en todos los casos analizados han sido fundamentales para la obtención de la integración, ya fuera para la consecución de un trabajo o como ayuda en la gestión de la documentación.

Manzani\&Arnoso, 2014, señalan que según las circunstancias anteriores de cada persona tendrá un nivel de motivación distinto. Sin embargo, atendiendo a los resultados obtenidos, existen distintas situaciones que motivan el proceso migratorio. Se encuentran familias estructuradas, desestructuradas, con nivel socioeconómico medio y bajo. En todos los casos el nivel de motivación por la consecución de su objetivo, “un futuro mejor”, ha sido el mismo. Han luchado muy duro por conseguir la documentación y un trabajo que les permita mejorar, no solo a ellos sino también a sus familias en su país de origen. En todos los casos han verbalizado tener sus objetivos claros, como aspecto ineludiblepara no desviarse de su camino y poder conseguir la integración. 
Debido aumento de menores inmigrantes, los Centros de acogida están sufriendo un incremento de población MENA (Gimeno Monterde, 2013). Este aspecto ha sido acusado por los participantes. Al destacar queel personal de Fuerte La Purísima, no puede dar una atención individual y de calidad, debido alelevado número de menores. Al igual que recalcan en algunos casos que hay niños mayores junto con los más pequeños, procediendo en ocasiones a abusos de poder. Este hecho podría mejorar siempre y cuando se pudiera contar con otras instalaciones para la creación de otro Centro donde se pudieran distribuir los niños por edades y perfil, para de esta manera unificar las pautas educativas, hecho que ayudaría al personala desarrollar su labora en mejores condiciones y además cabría la posibilidad de tutorizar a los menores. De esta forma, los menores tendrían una figura de referencia en ausencia de sus padres.

Dentro de esta investigación se ha encontrado la limitación de poder ampliar la muestra a mujeres, haciendo un análisis comparativo entre géneros. No se ha encontrado el mismo número de mujeres que de hombres. Según las conversaciones mantenidas con personal dedicado a este colectivo, al que se le solicitó información sobre las mujeres, son enviadas habitualmente, a Centros de la Península, y las que permanecen aquí suelen casarse y no se encuentran de manera activa dentro de la vida social. A modo de justificación, hay que destacar que el número de niñas que entran en los centros es muy inferior al número de niños que ingresan en los mismos.

A modo de recapitulación de todo lo analizado a lo largo del presente estudio, se puede afirmar que existen aspectosimportantes a trabajar por parte de los menores y del personal que se dedica a este sector, para que éstos puedan tener una satisfactoria integración. Ninguno de ellos, ha sido determinante para la integración ni se puede generalizar a todos los casos, puesto que cada uno ha utilizado distintas herramientas para conseguir la documentación. Esto hace que se fomenten todos los factores como un todo, sin destacar ninguno por separado.

Los factores que potencian una adecuada integración serían los siguientes:

- La edad de ingreso en el centro es muy importante, cuanto más jóvenes mejor. 
- El mantenimiento de una constancia dentro del centro de protección, sin causar baja -no pernoctar en el centro-.

- La participación de manera activa de las actividades propuestas por parte del centro.

- La realización de formación, ya sea reglada o no reglada.

- La adquisición formación ocupacional donde se realicen prácticas de empresa.

- $\quad$ El aprendizaje del idioma.

- El establecimiento de una red de contactos, a través de la formación y/o el deporte.

- La realización de deporte favorecehábitos saludables de vida, incompatibles con el consumo de drogas.

- El establecimiento de unos objetivos claros y reales, por parte del menor, y trabajar por ellos.

- El mantenimientodel nivel de motivación por los objetivos planteados.

- La creación la figura del tutor para llevar a cabo un seguimiento más individualizado de los menores.

- El fomento de las actividades donde se puedan relacionar con personas de la Ciudad receptora. Mejorando así su integración y favoreciendo su red de contactos.

- La creación de Centros de estancia, apoyo y orientación, para el proceso documental al llegar la mayoría de edad.

La decisión de poner en marcha el proceso de migración, según Gabriela Montero, (2007), puede ser de manera autónoma e individual o a través de la familia. Según las entrevistas realizadas se cuenta entre los participantes con las dos circunstancias. Además se ha de especificar que en algunas ocasiones ha sido organizada por parte de la familia extensa, que se hacía cargo de ellos por situaciones vividas, y en otros casos, han sido los propios padres quiénes los han traído a Melilla para su ingreso en el centro, con la certeza de que su hijo tendrá un futuro mejor. Aunque la decisión fuese tomada por la familia, o por la propia persona de manera autónoma, en ningún caso dejan de tener contacto con la familia, según los propios relatos. Este hecho hace que se plantee la idea de si se cumplen 
los requisitos y características para ser MENA. Se podría proponer trabajar con las familias, teniendo la posibilidad de reagrupación familiar en su país de origen.

Iniciar este duro proceso de migración es una decisión que marca la vida de estos jóvenes. Crecen siendo niños de nadie. Al iniciar la migración a edades tan tempranas se llega a producir un desarraigo de su País, sin embargo no así de sus familias, ya que mantienen los vínculos con ellos a través de los medios de los que disponen, llamadas telefónicas, visitas de los familiares y redes sociales.

\section{REFERENCIAS BIBLIOGRÁFICAS}

Aguilera González, M. (2014). Proyecto de intervención menores inmigrantes no acompañados. Universidad de Granada. Granada

Antúnez Álvarez, M; Driss Cotilla, N; García Rodríguez, R.; OlcinaVialplana, S. (2016). De niños en peligro a niños peligrosos. Una visión sobre la situación actual de los Menores Extranjeros no Acompañados. Asociación Harraga. Melilla

Añaños B., F. T.; Añaños B., K. G.; Arroyo A., S. \&Añaños H., C. (2010). Realidades y representaciones sociales de las niñas y los niños de la calle de Perú. Revista Española de Drogodependencias, 35 (2), 182-194

Araújo Moreira da Silva, L. \& Montserrat, C. (2014). Jóvenes que estuvieron en el sistema de protección social a la infancia. Reflexiones a partir de una investigación realizada en Girona, España. Psicología: Reflexäo e Crítica-Psychology -edición electrónica-, 27 (1), 198-206

Bhabha, J. (2008). IndependentChildren, InconsistentAdults: International ChildMigration and the Legal Framework.DiscussionPapers, $\mathrm{n}^{\circ}$ 2008-02. Florence: UNICEF. Recuperado de https://www.unicef-irc.org/publications/pdf/idp_2008_02.pdf

Bhabha, J. (2009). Arendt'sChildren: Do Today'sMigrantChildrenHave a RighttoHaveRights?. Human RightsQuarterly, 31, 410-451

Borges Blázquez, L. (2013). Inmigración y Políticas Públicas de Integración: La evolución de un proceso inacabado. Cuadernos Electrónicos de Filosofía del Derecho, 28, 3657 
Blancas Avilés, R. \& Belén Jurado, G. (2010). Estrategias de intervención social con jóvenes inmigrantes extutelados por el Servicio de Protección de Menores. Documentos de Trabajo Social, 47, 134-143

Bravo, A. \& Santos-González, I. (2015). Menores extranjeros no acompañados en España: necesidades y modelos de intervención. Intervención psicosocial 26 (1), 55-62

Cablemel TV (28 de enero de 2016). El Juez de Menores de Melilla: “El problema de los MENA no se va a solucionar" (Archivo de vídeo). Recuperado dehttp://www.youtube.com/watch?v=nTHhAormy-I

Cañas, J. A. (2017/25/03). Ceuta y Melilla piden ayuda al Gobierno por los menores migrantes. Elpais.com. Recuperado de http://politica.elpais.com/politica/2017/03/25/actualidad/1490458315 423 945.html

Carrasco, N.; García, J. \& Zaldívar, F. (2014). Estimación y caracterización de los antecedentes de protección de los menores infractores. Anuario de Psicología Jurídica, 24, 31-35

Cemlyn, S.J. \&Nye, M. (2012). Asylumseekeryoungpeople: Social workvalueconflicts in negotiatingageassessment in the UK. International Social Work, 55 (5), 675-688

Cepero Espinosa, S \&Herrera Clavero, F (2008). Perfil Psicológico-Afectivo de una muestra de niños de la calle de Ceuta. Revista Española de Orientación y Psicopedagogía, 19 (1), 1 cuatrimestre, 35-50

Cepero Espinosa, S.; Mohamed Mohand, L. \& Herrera Torres, L. (2016). Análisis comparativo de los niños de la calle de Ceuta, los de países en desarrollo y desarrollados. DEDiCA. REVISTA DE EDUCAÇÄO E HUMANIDADES, 9, 229243

Dalla, M.; Antoniou, A. S. \&Matsa, K. (2009). Inmigration, acculturationandrug abuse: multicultural of treatment. Antoniou, A. S., Cooper, C., Chrousos, G., Spielberger, C. \&Eysenck, M. W., Handbook of ManagerialBehavior and OccupationalHealth (362-377).

Dalrymple, J. K. (2006). SeekingAsylumAlone: UsingtheBestInterests of theChildPrincipletoProtectUnaccompaniedMinors.

Boston CollegeThirdWorldLawJournal, 26, 131-168

Derluyn, I. \&Broekaert, E. (2008). Unaccompaniedrefugeechildren and adolescents: Theglaringcontrastbetween a legal and psychologicalperspective. International Journal of Law and Psychiatry, 31, 319-330 
Drogodependencia en menores extranjeros no acompañados (MENA): su derecho a una educación y salud de calidad. Observatorio Vasco de drogodependencia. Descargado de http://www.euskadi.net/ejgvbiblioteka

Empez Vidal, N. (2007). Social construction of neglect: the case of unaccompaniedminorsfromMoroccotoSpain.

Mac

PlanchInstituteforDemographicResearch

Fernández Millán, J.M., Díez de la Cortina, D.; Malpica Buitrago, M. J. \&Hamido Mohamed, A. (2010). Relación entre el apoyo social, la satisfacción vital y las expectativas de futuro de menores acogidos en centros de protección. ElectronicJournal of Research in EducationalPsychology, 8 (2), 643-654

Fernández-Millán, J.M., Hamido-Mohamed, A., Fernández-Navas, M. (2011). Educación Social y atención a la infancia. Madrid: Pirámide

Fernández Millán, J. M.; Hamido Mohamed, A. \& Ortiz Gómez, M. M. (2009). Influencia del acogimiento residencial en los menores en desamparo. ElectronicJournal of Research in EducationalPsychology 7 (2), 715-728

Fernández Millán, J.M., Malpica Buitrago, M.J. \& Fernández Navas, M. (2010). Codificación y análisis diferencial de los problemas de los adolescentes acogidos en centros de protección en España. UniversitasPsychologica, 9 (3), 841-848

Fuentes Sánchez, R. (2014). Menores Extranjeros No Acompañados (MENA). Revista Internacional de Trabajo Social y Bienestar, 3, 105-111

Gabriela Monteros, S. (2007). La Construcción Social de un nuevo Sujeto Migratorio: Los Menores Migrantes Marroquíes no Acompañados. Condiciones de posibilidad para la agencia. (Tesis Doctoral). Universidad Autónoma de Madrid. Madrid

Gallego Obieta, V.; Martínez Soler, J.J.; Ortiz Barahona, A.; Pastor Valdés, M.; Pérez Burrull, I.; Valero Torrejón, M. (2006). La integración social de los menores inmigrantes no acompañados: Nuevos retos de la Comunidad de Madrid. Acciones e investigaciones sociales, ISSN 1132-192X

García Barriocanal, C.; Del a Herrán Gascón, A. \&Imaña Martínez, A. (2007). El Acogimiento Residencial como Medida de Protección al Menor. Una perspectiva desde la experiencia de jóvenes ex-residentes y sus familiares. Propuesta de Mejora. Defensor del Menor en la Comunidad de Madrid. Madrid

García Fernández, M. D. (2002). Los niños de la calle en Brasil ¿una subcultura a eliminar?. Revista Española de Educación Comparada, 8, 41-60 
Gimeno Monterde, C. (2013). Menores que migran solos y sistemas de protección a la infancia. Zerbitzuan. Revistas de Servicios Sociales, 53, 109-122

Gómez-Fraguela, J., Luengo-Martín, A., Romero-Triñanes, E., Villar-Torres, P. \& SobralFernández, J. (2006). Estrategias de afrontamiento en el inicio de la adolescencia y su relación con el consumo de drogas y la conducta problemática.International Journal of Clinical and Health, Psychology, 6, 581-597

González Báez, A. P. (2009). Intervención Psicológica con Menores Extranjeros no Acompañados desde un Equipo de Intervención Especializada. ISSN 1988-494X. Descargado de http://www.psicologia.ull.es/archivos/revista/articulos\%20ripla\%2009/Menores\%2 0no\%20acompa\%C3\%B1ados.pdf

Gutiérrez Sánchez, J. D. \&Diz Casal, J. (2017). Cooperación Internacional en Marruecos: empoderamiento para insertar socio-laboralmente a jóvenes en contextos de riesgo. Cuadernos de Trabajo Social, 30 (1), 163-174

Herrera Hernández, J.M., Barranco Expósito, M.C., Rosveriz Lorenzo Machín, N., González Rodríguez, N. \& Hernández García, R. (2002). Psicoeducación grupal con menores inmigrantes no acompañados. Alternativas. Cuadernos de Trabajo Social, 10, 369-378

Huebner, E. (1991). InitialDevelopment of theStudent'sLifeSatisfactionScale. Social Psychology International, 12, 231-240.

Jariot García, M.; Sala Roca, J. \& Arnau Sabatés, L (2015). Jóvenes Tutelados y Transición a la vida independiente: indicadores de éxito. Revista Española de Orientación y Psicopedagogía, 26 (2), 99-103

Jimenez, M. (2015). AutonomousChildMigration at theSouthernEuropeanBorder. Centro de Investigaço e as Organizaçöes (CIEO), University of Algarve, Faro, Portugal

Jiménez Álvarez, M. (2014). Intrusos en la fortaleza. Menores marroquíes migrantes en la Frontera Sur de Europa. Universidad Autónoma de Madrid. Madrid

Khachani, M. (2004). ¿Por qué emigran los jóvenes marroquíes?. El deseo de perseguir obstinadamente el sueño europeo se alimenta de las dificultades económicas y sociales que afrontan las nuevas generaciones. Asociación Marroquí de Estudios e Investigaciones sobre las Migraciones (AMERM). AFKAR/IDEAS

Laespada Martínez, M.T.; AñañosBedriñana, F. T.; Arbex Sánchez, C.; Arana Berastegi, X.; de Inocencio Biangel, R.; CabrejasLalade, A.; Joménez Ramírez, F. J.; Gómez Pérez de Arenaza, M.; Acebo Urretxu, A.; Moreno Arnedillo, G.; Otano López, J. 
L.; Pardo Urdin, A. (2005). Los menores vulnerables y su relación con las drogas. Avances en drogodependencias. Bilbao: Universidad de Deusto

Lafuente Castellano, E. (2010). Menores inmigrantes no acompañados (MENAS). Fórum de recerca, 15, 495-504. Universidad Jaume I. Recuperado de http://repositori.uji.es/xmlui/handle/10234/77768

Ley Orgánica 8/2000, de 22 de diciembre, de reforma de la Ley Orgánica 4/2000, de 11 de enero, sobre derechos y libertades de los extranjeros en España y su integración social

Ley Orgánica 1/1996, de 15 de enero, de Protección Jurídica del Menor, de modificación parcial del Código Civil y de la Ley de Enjuiciamiento Civil

Ley Orgánica 5/2000, de 12 de enero, reguladora de la responsabilidad penal de los menores

López, M.; Santos, I.; Bravo, A. \& del Valle, J. F. (2013). El proceso de transición a la vida adulta de jóvenes acogidos en el sistema de protección infantil. Anales de Psicología, 29 (1), 187-196

Lozano, A. (2016/14/08). El maestro en cortar jamón en Melilla. Un musulmán inmigrante.

El Español.com. Recuperado de http://www.elespanol.com/reportajes/grandeshistorias/20160813/147485706_0.html

Manzani, L. \&Arnoso Martínez, M. (2014). Bienestar psicosocial en menores y jóvenes extranjeros sin referente familiar adulto: factores de riesgo y protección. Norte de salud mental, vol. XII, 49, 33-45

Melilla acoge actualmente a más de 500 MENA frente a ninguno en 1997 (2016/03/12). La Vanguardia. Recuperado de http://www.lavanguardia.com/vida/20161203/412376633486/melilla-acogeactualmente-a-mas-de-500-menas-frente-a-ninguno-en-1997.html

Melilla.eshttp://www.melilla.es/melillaportal/contenedor.jsp?seccion=s_fdes_d4_v1.jsp\&c odbusqueda $=182 \&$ language $=$ es \&codResi $=1 \& \operatorname{codMenuPN}=601 \& \operatorname{codMenuSN}=2 \&$ codMenuTN=152\&codMenu=309\&layout=contenedor.jsp

Merino, O. (2017/21/05). Por encima de todo lo demás, está la libertad. El periódico.com. Recuperado de http://http://www.elperiodico.com/es/noticias/entre-todos/porencima-todo-demas-esta-libertad-6051761

Moreno Márquez, G. (2012). Actitudes y opinión sobre los menores extranjeros no acompañados en la Comunidad Autónoma del País Vasco. Migraciones, 31, 43-68 
Novales Casado, A. (2015). La reintegración de menores en las familias inmigrantes. Riesgos y necesidades de los menores inmigrantes reagrupados. Cuadernos de Trabajo Social, 28 (2), 235-243

Ochoa de Alda Martínez de Apellániz, I.; Antón Romero, J.; Rodríguez Nieto, A. \&AtabiSakia, H (2009). La importancia del trabajo con la familia en la atención a menores extranjeros no acompañados. Un estudio piloto. Apuntes de Psicología, 27 (2-3), 427-439

Pecora, P.J.; Kessler, R.C.; O’Brien, K.; Roller White, C.; Williams, J; Hiripi, E.; English, D.; White, J.; Herrick, M.A. (2006). Educational and Employmentoutcomes of adultsformerly placed in Foster care: ResultsfromtheNorthwest Foster CareAlumniStudy. Elsevier. ScienceDirect.Children and YouthServicesReview,28, pp 1459-1481

Rodríguez García de Cortázar, A. (2015/2016). Chicos Marroquíes buscando su futuro: La experiencia de migrar, entre la violencia estructural y las violencias cotidianas. (Tesis Doctoral). Universidad de Granada. Granada

Saiz Manzanares, M.C. \& Román Sánchez, J.M. (1996). Entrenamiento de niños socialmente desfavorecidos en habilidades para resolver problemas sociales. Revista de Psicología General y Aplicada, 49 (2), 309-320

Samper, P.; Tur, A. M.; Mestre, V. \& Cortés, M. T. (2008). Agresividad y afrontamiento en la adolescencia. Una perspectiva intercultural. International Journal of Psychology and PsycologicalTherapy, 8, 3, 431-440

Sinclair, I; Baker, C.; Wilson, K.; Gibbs, I. (2005). Foster Children: Wheretheygo and howtheygeton. Jessica KingsleyPublishers. London.

Sotomayor Morales, E. \& De la Fuente Robles, Y. (2012). Derechos humanos de la infancia en los procesos migratorios de Marruecos a España. Trabajo Social, 14, $145-164$

Soto-Lesmes, V. \& Durán de Villalobos, M. M. (2010). El trabajo de campo: clave en la investigación cualitativa. Aquichan, Chía, 10 (3), 253-266

Torrado Martín-Palomino, E. (2012). Las migraciones de menores no acompañados desde una perspectiva de género. Dilemata, 10, 65-84

Torres Pérez, F. (2008). Amigos, sociabilidad adolescente y estrategias de inserción de los hijos de migrantes ecuatorianos en la región de Murcia. En Herrera, G. \& Ramírez, J. América Latina migrante: Estado, familias, identidades (361-376). Ecuador: Flacso 
Yufra, L. C. (2016). El trabajo que no se ve. Dispositivos de inserción sociolaboral para mujeres inmigrantes en Barcelona. Revista de Metodología de Ciencias Sociales, $33,15-36$ 
Anexo 1: Entrevista de Evaluación.

\section{ENTREVISTA}

1. ¿De dónde eres?

2. ¿Con quién vivías en casa?

a. Hermanos

b. Padre/madre.

3. ¿Crees que teníais todo lo necesario para vivir bien?, ¿Crees que era necesario que entrara más dinero en tu casa?

a. Describe tu casa, cuántas habitaciones tenía, decoración...

b. ¿A qué se dedica tu padre/madre?

4. ¿¿ué te motivó a venir a Melilla?

5. ¿Te encontrabas bien en casa?¿Cómo era la relación con tus padres y con tus hermanos (en el caso de que los tuviera)? (Tenías problemas en casa)

6. ¿Había una buena comunicación familiar, entre tú y tus padres? ¿Y entre tus padres, cómo era la relación? (violencia de género, violencia filioparental)?

7. ¿En tu familia había algún tipo de consumo (antecedente) de alguna sustancias tóxicas?

8. ¿Por qué te decidiste venir a Melilla?

9. ¿Cómo organizaste tu viaje?

a. Contacto con alguien

b. Dinero

c. Algún tipo de trámite previo

10. ¿Cuándo llegaste a Melilla?

11. Cuando llegas a Melilla ¿qué es lo primero que hiciste?

12. ¿Conocías a alguien previamente?

13. ¿Cómo llegas al Centro?

14. ¿Cómo era tu vida en el Centro? Cuéntame un día allí

15. ¿Qué oportunidades te dieron en el Centro?

16. ¿Hiciste algún curso de formación?

17. ¿Conocías el idioma? ¿cómo lo aprendiste?

18. Una vez que llegas a Melilla, ¿Has consumido algún tipo de sustancias tóxicas? 
19. ¿Qué cambiarías de tu vida en el Centro?

20. ¿Cómo conseguiste trabajo?

21. ¿Dónde viviste una vez que cumpliste la mayoría de edad?

22. ¿Piensas que todos los niños tenéis las mismas oportunidades?

23. ¿Qué piensas de otros menores que han tenido las mismas oportunidades que tú, pero no están trabajando como tú?

24. ¿Qué consideras que ha hecho que tengas una buena inserción a diferencia de otras personas que no lo consiguen?

25. ¿Tienes contacto con tu familia?

26. ¿Cómo te sientes en Melilla? (sentimiento de pertenencia)

27. ¿Te gustaría volver a tu casa de nuevo?

28. ¿Cuáles son tus objetivos? ¿qué quieres conseguir en el futuro? 
Anexo 2: Transcripción de las entrevistas realizadas.

- ENTREVISTA 1: Mohand, 24.

1. ¿DE DÓNDE ERES?

Un pueblo cerca de Guasasa que se llamaTinerhir

\section{1. ¿ESTÁ CERCA DE DÓNDE?}

Un poquito más lejos de la zona de Marrackech al sur, al oeste.

\section{2. ¿CON QUIÉN VIVÍAS EN TU CASA?}

Con mi familia.

\section{1. ¿QUIÉN ES TU FAMILIA?¿CUÁNTOS HERMANOS TIENES?}

Tengo cuatro hermanos, yo soy el quinto. Con mi padre y mi madre

\section{2. ¿TU PADRE Y TU MADRE TRABAJAN?¿TRABAJABAN CUANDO TE VINISTE A MELILLA?}

Mi padre sí. Mi padre trabajaba de vez en cuando, ahora trabaja. Mi madre es ama de casa.

\subsection{1. ¿DE QUÉ TRABAJABA DE VEZ EN CUANDO?}

Trabajaba de mecánico.

3. ¿CREES QUE TENÍAIS TODO LO NECESARIO PARA VIVIR BIEN? ¿CREES QUE ERA NECESARIO QUE ENTRARA MÁS DINERO EN TU CASA?

Para comida no faltaba ¡claro!. Pero uno pensaba en el futuro donde va a vivir y de qué iba a trabajar, y por eso piensas en venir a otras ciudades, Nador, Melilla o colarse en la Península.

\section{1. ¿CÓMO ERA TU CASA? ¿CUÁNTAS HABITACIONES TENÍA?}

Una casa normal y corriente, tenía dos habitaciones, un baño, un salón, cocina.

4. ¿TE ENCONTRABAS BIEN EN CASA? ¿CÓMO ERA LA RELACIÓN CON TUS PADRES Y CON TUS HERMANOS? (TENÍAS PROBLEMAS EN CASA) 
En mi casa estaba todo bien. El problema es que tenía la enfermedad celíaca. Me lo detectaron aquí en Melilla. En Marruecos decían los médicos que era anemia, pero cuando vine a Melilla, me dijeron que era celiaco.

5. ¿HABÍA UNA BUENA COMUNICACIÓN CON TU FAMILIA, ENTRE TÚ Y TUS PADRES? ¿Y ENTRE TUS PADRES, CÓMO ERA LA RELACIÓN? (VIOLENCIA DE GÉNERO, VIOLENCIA FILIOPARENTAL)

Había muy buena relación con mis padres, con mis hermanos y con toda la familia.

6. ¿EN TU FAMILIA ABÍA ALGÚN TIPO DE CONSUMO (ANTECEDENTE) DE ALGUNA SUSTANCIA TÓXICA?

No, nadie, ni mi padre, ni mis hermanos ni yo tampoco. Ninguno.

\section{7. ¿QUÉ TE MOTIVÓ PARA VENIR A MELILLA?}

Mejorar uno, cambiar de vida, buscar un trabajo.

\section{1. ¿ ¿NO PENSASTE QUE EN TU PUEBLO PODRÍAS TRABAJAR?}

Sí, pero aquí mejor, más cosas, más oportunidades.

\section{8. ¿CÓMO ORGANIZASTE TU VIAJE?}

Me dijeron hace tiempo que en Melilla te puedes buscar la vida, se lo dijeron a mi madre y mi madre me preguntó que qué me parecía, a mi me pareció bien. A la semana dejé los estudios y vine para Melilla.

Vine en autocar hasta Nador, estuve con un hombre que conocía mi padre. Estuve en su casa durante 2 o 3 meses. De vez en cuando me acercaba a la frontera para ver cómo iba, como se entraba.

Crucé la frontera por Barrio Chino, echándole una mano a una mujer con las bolsas y ya no volví a entrar.

Traje muy poco dinero, casi nada. No me hizo falta más dinero.

9. ¿CUÁNDO LLEGAS A MELILLA? 
Hace unos diez años más o menos.

\section{CUANDO LLEGASTE A MELILLA ¿QUÉ ES LO PRIMERO QUE HICISTE?}

Lo primero que hice fue preguntar dónde estaba la Policía Local, para que me llevaran al centro de menores. Me dijeron donde estaba, me fui para allá, me hicieron una ficha, con un montón de preguntas y me llevaron al centro de menores.

\section{1. ¿CONOCÍAS A ALGUIEN QUE HABÍA REALIZADO ESE TRÁMITE?}

Sí los conocía y todo bien.

\section{2. ¿CÓMO LLEGAS AL CENTRO?}

Me llevó la Policía Local, porque yo me dirigí allí.

\section{3. ¿CÓMO ES TU VIDA EN EL CENTRO?}

Los primeros días fueron difíciles, hay mucha gente que no conoces de nada, también fue difícil por el idioma, porque hay gente que hablaba tamazigh de aquí y también árabe y algunos educadores hablaban español. Hasta que uno va acostumbrándose una semana, dos, un mes... el primer año fue difícil.

\section{4. ¿QUÉ OPORTUNIDADES TE DIERON EN EL CENTRO?}

Aprender el idioma, me detectaron que era celíaco, que eso no lo sabía. Conocer a un montón de gente.

\section{5. ¿HICISTE ALGÚN CURSO DE FORMACIÓN?}

Estudiar un PCPI de cocina, he trabajado en un plan de empleo, he hecho un PCPI de mecánica.

\section{6. ¿CONOCÍAS EL IDIOMA? ¿CÓMO LO APRENDISTE?}

No lo aprendí en el centro.

17. UNA VEZ QUE LLEGAS A MELILLA, ¿CONSUMES ALGÚN TIPO DE DROGA?

No, nada. 


\section{8. ¿QUÉ CAMBIARÍAS DE TU VIDA EN EL CENTRO?}

Ahora han quitado cosas, por ejemplo la COA. Se quejaban de que hay mucha gente, antes éramos menos niños. Dar clase a todos lo niños que están allí, aunque sean mayores o pequeños.

\section{9. ¿CÓMO CONSEGUISTE EL TRABAJO?}

Ahora estoy trabajando en cocina y lo conseguí a través de compañeros que estuvieron conmigo en el centro y estaban trabajando, fui preguntando y me avisaron cuando hubo un sitio.

\section{0. ¿DÓNDE VIVISTE UNA VEZ QUE CUMPLISTE LA MAYORÍA DE EDAD?}

Me fui a Marruecos, ahora es otro libro. Me fui a Marruecos, pedí la tarjeta de residencia, me pidieron un montón de papeles, como un precontrato, papeles de que no estás casado...

Encontré el precontrato preguntando a todas las personas que conozco, a todos mis amigos, por todos los locales, hasta que lo conseguí. Entregué mi Currículo a un montón de sitios.

\section{1. ¿PIENSAS QUE TODOS LOS NIÑOS TENÉIS LAS MISMAS OPORTUNIDADES?}

A veces, no sé. Si viene un menor de edad que tiene 13 años, sí tiene oportunidades, pero si viene con 17 años, tiene muy pocas.

\section{2. ¿QUÉ PIENSAS DE OTROS MENORES QUE HAN TENIDO LAS MISMAS OPORTUINIDADES QUE TÚ, PERO NO ESTÁN TRABAJANDO COMO TÚ?}

Bueno si tú estás en el centro siguiendo las normas vas a salir bien, pero si estás en el centro y bajas a robar y de vez en cuando peleas y eso no vas a conseguir nada.

Hay algunos niños que han venido pequeños como yo, pero no han conseguido nada, porque piden cosas que son casi imposibles. Por ejemplo un menor que viene y que no tiene familia en Marruecos y le piden para la documentación un pre-contrato, normalmente no te van a dar un pre-contrato si no tienes la tarjeta de residencia. 
23. ¿QUÉ CONSIDERAS QUE HA HECHO QUE TENGAS UNA BUENA INSERCIÓN A DIFERENCIA DE OTRAS PERSONAS QUE NO LO CONSIGUEN?

Es necesario quedarte en el centro hasta que cumplas 18 años. También es importante venir a Melilla siendo pequeño. También es importante el tiempo que estés en el centro.

Yo lo conseguí, moviéndome mucho, pidiendo favores a la gente que conocía.

Porque hay veces y personas que no aguantan las normas, no aguantan dormir a las 22:00 o levantarse a las 8:00 de la mañana, desayunar. No aguanta ir al colegio, ir a estudiar. Normas que son nuestro derecho y tener una vida normal y algunos no la soportan.

\section{4. ¿TIENES CONTACTO CON TU FAMILIA?}

Sí tengo contacto con mi familia, desde siempre. No he dejado de tener contacto con ellos.

\section{5. ¿CÓMO TE SIENTES EN MELILLA?}

Me encuentro bien. Me siento melillense.

\section{6. ¿TE GUSTARÍA VOLVER A TU CASA DE NUEVO?}

Volver para quedarme allí, mejor no.

\section{7. ¿CUÁLES SON TÚS OBJETIVOS? ¿QUÉ QUIERES CONSEGUIR EN EL FUTURO?}

De momento tengo trabajo y quiero quedarme aquí.

28. ¿QUÉ CONSEJO LE DARÍAS A LOS MENORES QUE ESTÁN EN LA CALLE? Que se queden en el centro de menores, disfrutando de los estudios. Que no hagan tonterías. Que piensen qué va a hacer de aquí a 5 o 6 años, estudiar y aprovechar el tiempo.

\section{9. ¿RECOMENDARÍAS A ALGUIEN, A UN HERMANO VENIR?}

Sí, claro que lo recomendaría, además le diría cuáles son las normas que tiene que seguir para poder tener una vida normal. 
- $\quad$ ENTREVISTA 2: Kemel, 25.

1. ¿DE DÓNDE ERES?

Yo soy de Guasasat, la garganta del Todrah. Muy lejos 1.200 km más o menos, 11 horas casi de viaje.

\section{2. ¿CON QUIÉN VIVÍAS EN TU CASA?}

Con mi familia, mis padres y mis hermanos. Somos dos hermanos y dos hermanas.

Ahora vive en casa mi madre, mi abuela, un hermano y una hermana. Hay una hermana que está casada allí en el pueblo.

\section{3. ¿TU PADRE Y TU MADRE TRABAJAN?¿TRABAJABAN CUANDO TE VINISTE A MELILLA?}

Mi padre antes se dedicaba a la hostelería, pero no le pagaban bien, le pagaban 2 francos todos los meses. Falleció en la cafetería donde trabajaba. Y mi madre vive del dinero que le mando yo todos los meses. Le mando aproximadamente 400-500€ y con eso viven bien.

\section{4. ¿CREES QUE TENÍAIS TODO LO NECESARIO PARA VIVIR BIEN? ¿CREES QUE ERA NECESARIO QUE ENTRARA MÁS DINERO EN TU CASA?}

Teníamos lo necesario para vivir. No para vivir bien, pero teníamos lo básico. Para comer, vestirnos y no nos podíamos permitir muchos lujos ni caprichos.

Creo que sí hacía falta que entrara más dinero en casa para los gastos de la casa, la ropa y todo eso.

\section{1. ¿CÓMO ERA TU CASA? ¿CUÁNTAS HABITACIONES TENÍA?}

Mi casa tenía una cocina, un cuarto de baño, un salón y el cuarto de mi madre y mi padre. Nosotros dormíamos en el salón todos juntos.

Ahora he hecho una casa, una casa que tiene dos pisos. Es mía pero vive mi familia allí.

La casa que te he descrito antes era la antigua de barro, ahora con un poquito de esfuerzo tenemos una casa mejor. La casa de ahora tiene abajo tres habitaciones, un salón, la cocina 
y un cuarto de baño y arriba tiene una salita dos cuartos y arriba la azotea, aunque allí he hecho dos habitaciones también.

5. ¿TE ENCONTRABAS BIEN EN CASA? ¿CÓMO ERA LA RELACIÓN CON TUS PADRES Y CON TUS HERMANOS? (TENÍAS PROBLEMAS EN CASA).

Económicamente no estábamos bien. No había mucho dinero para mantener a la familia y veía que no había nadie que trabajara por la familia, por eso decidí salir de la casa y sacar a la familia para delante.

Nos llevábamos bien toda la familia.

6. ¿HABÍA UNA BUENA COMUNICACIÓN CON TU FAMILIA, ENTRE TÚ Y TUS PADRES? ¿Y ENTRE TUS PADRES, CÓMO ERA LA RELACIÓN? (VIOLENCIA DE GÉNERO, VIOLENCIA FILIOPARENTAL).

La relación con todos los miembros de la familia era buena, teníamos buena comunicación y no había ningún tipo de problema entre nosotros. Me llevaba muy bien con ellos. Solo había problemas a nivel económico.

7. ¿EN TU FAMILIA HABÍA ALGÚN TIPO DE CONSUMO (ANTECEDENTE) DE ALGUNA SUSTANCIA TÓXICA?.

Nadie consumía drogas ni tampoco tenía ninguna enfermedad grave.

8. ¿QUÉ TE MOTIVÓ PARA VENIR A MELILLA?

Poder tener una vida mejor. Nadie me contó nada sobre Melilla, mi idea inicial era ir a Nador a trabajar. Una vez que llegue a Nador supe que estaba Melilla, que era una ciudad española cerca de Nador, fue todo casualidad.

Una vez que llegué a Nador conocí gente que me aconsejó venir a Melilla y les hice caso.

\section{1. ¿NO PENSASTE QUE EN TU PUEBLO PODRÍAS TRABAJAR?}

Pensé en trabajar en Nador, porque en mi pueblo no había trabajo.

9. ¿CÓMO ORGANIZASTE TU VIAJE? 
Tenía un billete marroquí de 100 dirhans en el bolsillo. No lo hablé con mis padres, ni con nadie. Yo hice una locura, solo con mi billete de 100 dirhans.

10. ¿CUÁNDO LLEGAS A MELILLA?

Llevo en Melilla casi 10 años.

\section{CUANDO LLEGASTE A MELILLA ¿QUÉ ES LO PRIMERO QUE HICISTE?}

Primero busqué a la Policía Local, hablar con ellos para que te puedan subir al centro. Tú solo no puedes ir al centro porque sí.

\section{2. ¿CONOCÍAS A ALGUIEN QUE HABÍA REALIZADO ESE TRÁMITE?}

No conocía a nadie que hubiera hecho este proceso. A mi me dieron los consejos las personas que había en la frontera y seguí los pasos que me dijeron.

\section{3. ¿CÓMO LLEGAS AL CENTRO?}

Llego al centro a través de la Policía Local, primero tienes que ir allí, te hacen unas preguntas y luego te suben al centro.

\section{4. ¿CÓMO ES TU VIDA EN EL CENTRO?}

El centro está muy bien. En ese momento estás conociendo un sitio nuevo a gente nueva y tienes que adaptarte, pero bien.

\section{5. ¿QUÉ OPORTUNIDADES TE DIERON EN EL CENTRO?}

El centro me ha dado mucho. Lo primero fue conocer el idioma, cuando llegué no sabía decir ni “hola” y allí nos enseñaron el idioma.

\section{6. ¿HICISTE ALGÚN CURSO DE FORMACIÓN?}

Sí hice varios cursos, carpintería de madera, carpintería de aluminio, camarero, pastelería. Y gracias al centro salí con títulos y por eso he podido encontrar el trabajo. También estuvo haciendo atletismo.

\section{7. ¿CONOCÍAS EL IDIOMA? ¿CÓMO LO APRENDISTE?}

Cuando llegué a Melilla no sabía nada del idioma, en el centro es lo primero que hicimos y ahora no lo hablo muy bien, pero bueno. 
18. UNA VEZ QUE LLEGAS A MELILLA, ¿CONSUMES ALGÚN TIPO DE DROGA?

A mi no me gusta, no he consumido ni tabaco, ni hachís, ni alcohol, nada de nada.

\section{9. ¿QUÉ CAMBIARÍAS DE TU VIDA EN EL CENTRO?}

No cambiaría nada de mi vida en el centro. Está todo bien.

\section{0. ¿CÓMO CONSEGUISTE EL TRABAJO?}

Son casualidades que te manda la vida. Primero hice el curso de pastelería y allí hice muchas tartas y muchas cosas, era muy espabilado; así que cuando terminé, la profesora habló con el director para que pudiera quedarme haciendo cocina. El director del centro me llamó y me dijo que la gente de la escuela estaba muy contento conmigo y que querían que siguiera con ellos haciendo otro curso. Yo insistí para poder hacer cocina, aunque el director insistió para que hiciera el de camarero, porque me dijo que valía para eso, así que al final hice el de camarero.

A partir de ahí estuve haciendo prácticas, gané el premio del mejor cortador de jamón y de ahí me mandaron a hacer prácticas. Las prácticas son solo un mes. Ahí tienes que estar muy espabilado y hacer mucho, me vieron que valía y gracias a las prácticas encontré el trabajo.

\section{1. ¿DÓNDE VIVISTE UNA VEZ QUE CUMPLISTE LA MAYORÍA DE EDAD?}

Una vez que salgo del centro con 18 años, no tenía nada. Salí con un papel blanco que caducaba ese mismo día. Tampoco contaba con el precontrato y no te dan muchas oportunidades para moverte.

Yo tengo que agradecerle todo al hermano del dueño donde hice las prácticas que me ayudó a hacer los papeles de la documentación.

Te encuentras en una situación difícil, porque si te vas del trabajo para hacer el pasaporte marroquí, que es un documento que te piden para el permiso de trabajo, tienes que estar unos días en Marruecos, existe la posibilidad de perder el trabajo, pero si no haces ese 
trámite no tienes posibilidades de conseguir la documentación, por lo que es una situación muy difícil.

Al final estuve trabajando hasta que me dieron unos días de permiso, que aproveché para hacer el pasaporte, y como había demostrado que trabajaba bien y que tenía interés, me respetaron mi puesto de trabajo.

\section{2. ¿PIENSAS QUE TODOS LOS NIÑOS TENÉIS LAS MISMAS OPORTUNIDADES?}

Sí, todos tenemos las mismas oportunidades. El centro es igual para todos.

\section{3. ¿QUÉ PIENSAS DE OTROS MENORES QUE HAN TENIDO LAS MISMAS OPORTUINIDADES QUE TÚ, PERO NO ESTÁN TRABAJANDO COMO TÚ?}

Hay algunos que tienen ganas de sacar su futuro hacia delante y ayudar a su familia y algunos que son unos vagos. Si eres vago y no quieres hacer nada y no quieres ayudar a tu familia. Tienen la idea de ir a colarse a la Península, se creen que allí van a estar mejor.

Yo creo que todos tenemos las mismas oportunidades y todos podemos hacer algo en esta vida. No digamos que este es mejor que otro, no hay nadie mejor que nadie. Uno tiene que depender de él mismo, pueden ir al centro, levantarse por la mañana ir a un curso, preguntar y hacer muchas cosas y no estar hasta las 10 de la mañana durmiendo y dar vueltas y vueltas y a los 18 años decir que no has tenido suerte, la suerte hay que buscarla.

\section{4. ¿QUÉ CONSIDERAS QUE HA HECHO QUE TENGAS UNA BUENA INSERCIÓN A DIFERENCIA DE OTRAS PERSONAS QU NO LO CONSIGUEN?}

La diferencia ha sido que me he adaptado a las normas, me he levantado temprano he hecho cursos y me he esforzado mucho en los cursos. No me he quedado durmiendo y dando vueltas por las calles, he aprovechado el tiempo, he buscado mi suerte.

\section{5. ¿TIENES CONTACTO CON TU FAMILIA?}

Una vez que llegué a Melilla y estaba en el Centro y me pude buscar la vida, entonces me compré un teléfono y ya pude tener contacto con ellos para poder hablar con ellos. 
Sí tengo contacto con mi familia de manera regular, desde que llegué al centro y conseguí el teléfono.

\section{1 ¿QUÉ QUIERE DECIR “ME BUSCABA LA VIDA”?}

Pues en la calle, aparcando los coches. En un curso que hice de carpintería de aluminio, hicimos las ventanas del mercado del rastro, nos daban algo de dinero, ese dinero era lo que utilizaba.

\section{6. ¿CÓMO TE SIENTES EN MELILLA?}

En Melilla me siento como uno más. Me encuentro bien.

\section{7. ¿TE GUSTARÍA VOLVER A TU CASA DE NUEVO?}

Bueno me gustaría volver cuando esté viejo, cuando tenga 70 años. Para la jubilación, para cuidar de los nietos.

\section{8. ¿CUÁLES SON TU OBJETIVOS? ¿QUÉ QUIERES CONSEGUIR EN EL FUTURO?}

Me gustaría poder abrir un negocio propio y no ser siempre un trabajador, casarme y tener una familia. Me gustaría quedarme en Melilla.

\section{9. ¿QUÉ CONSEJO LE DARÍAS A LOS MENORES QUE ESTÁN EN LA CALLE?}

Le diría que se fueran al centro y que se pusiera a estudiar y sacarse su futuro para delante. Estando en la calle, lo que están haciendo es echar su vida a perder.

Yo le doy consejo a estos niños, cuando los veo hablo con ellos y se lo digo.

\section{- ENTREVISTA 3: Karim, 24.}

1. ¿DE DÓNDE ERES?

Soy de Tinerhir, cerca de Rachidia.

\section{2. ¿CON QUIÉN VIVÍAS EN TU CASA?}

Antes de venir a Melilla vivía con mi familia, con mis padres y mis hermanos. Somos 6 hermanos y dos hermanas. 
3. ¿TU PADRE Y TU MADRE TRABAJAN?¿TRABAJABAN CUANDO TE VINISTE A MELILLA?

Mi padre era carnicero y mi madre ama de casa. En el momento en el que vengo a Melilla, mi padre estaba trabajando.

\section{4. ¿CREES QUE TENÍAIS TODO LO NECESARIO PARA VIVIR BIEN? ¿CREES QUE ERA NECESARIO QUE ENTRARA MÁS DINERO EN TU CASA?}

Sí teníamos todo lo necesario para vivir, lo que pasa que en Marruecos tienes para vivir un $50 \%$.

En mi casa no ha faltado de nada. Aunque yo soy una persona que me di cuenta que en el colegio, en los estudios, no iba a llegar lejos, así que decidir emigrar.

\section{1. ¿CÓMO ERA TU CASA? ¿CUÁNTAS HABITACIONES TENÍA?}

La casa que teníamos tenía cuatro habitaciones, cocina, cuarto de baño, azotea, jardín, una casa grande.

5. ¿TE ENCONTRABAS BIEN EN CASA? ¿CÓMO ERA LA RELACIÓN CON TUS PADRES Y CON TUS HERMANOS? (TENÍAS PROBLEMAS EN CASA). La relación con toda mi familia era muy buena, con mis padres y mis hermanos, todos nos llevábamos muy bien.

El mayor era un poco rebelde, le gustaba la fiesta y ha sido algo más problemático, pero ahora está casado. Fue cosa de la edad.

6. ¿HABÍA UNA BUENA COMUNICACIÓN CON TU FAMILIA, ENTRE TÚ Y TUS PADRES? ¿Y ENTRE TUS PADRES, CÓMO ERA LA RELACIÓN? (VIOLENCIA DE GÉNERO, VIOLENCIA FILIOPARENTAL).

Nunca me han gritado mis padres, ni me han castigado, hemos tenido siempre una buena relación y la comunicación ha sido muy buena.

La relación entre mis padres también era muy buena. No tenían problemas y se llevaban muy bien. 


\section{7. ¿EN TU FAMILIA HABÍA ALGÚN TIPO DE CONSUMO (ANTECEDENTE) DE ALGUNA SUSTANCIA TÓXICA?.}

Sólo tabaco mi padre.

\section{8. ¿QUÉ TE MOTIVÓ PARA VENIR A MELILLA?}

Me comentaron que había un centro de menores, que cuando estabas un tiempo conseguías los papeles y después podías trabajar y así conseguir un futuro seguro.

\section{9. ¿CÓMO ORGANIZASTE TU VIAJE?}

Mayo de 2007, estaba en clase y estaba pensando que podía seguir estudiando en el colegio o emigrar, y directamente me despedí de todos los profesores, de los compañeros y de ahí me fui directamente. Con 14 años. Estaba en $7^{\circ}$.

Llegué a Melilla con 14 años.

Me vine en autobús hasta Farhana con un primo mayor, y me quedé con unos familiares un tiempo, durante un mes. Y después pasé sin problema por la frontera de Barrio Chino. Pasé como si nada y solo eso, aquí estamos. Pasé ayudando a una mujer con las bolsas y ya me quedé.

Vine en autobús que salía las 16:00 de la tarde y llega aquí a las 6:00 de las mañana.

Fue como un viaje de vacaciones de curso y vinimos. Mi primo se volvió a Marruecos.

10. ¿ CUÁNDO LLEGAS A MELILLA?

Llegué a Melilla con 14 años.

\section{CUANDO LLEGASTE A MELILLA ¿QUÉ ES LO PRIMERO QUE HICISTE?}

Una vez que paso por Barrio Chino y me quedo en Melilla, lo primero que hago es ir a la Policía Local para que me lleven al Centro.

12. ¿CONOCÍAS A ALGUIEN QUE HABÍA REALIZADO ESE TRÁMITE? 
Ya tenía la información porque tenía amigos y primos y familiares que ya habían realizado este viaje. Estábamos en contacto por las redes sociales, Facebook, Messenger...

\section{3. ¿CÓMO LLEGAS AL CENTRO?}

Una vez que entro me dirijo a la Policía Local, como me habían dicho que tenía que hacer y de ahí me llevaron al Centro "La Purísima”.

\section{4. ¿CÓMO ES TU VIDA EN EL CENTRO?}

Primero llegué al módulo de arriba (módulo de primera acogida) y a los tres o cuatro días me bajaron al módulo de Avicena (el módulo donde se agrupan los niños de más corta edad) y ya directamente me apuntaron a Enrique Nieto para estudiar, pero por la tarde, por eso no pude aprovechar para sacarme la ESO, porque tenía que haber ido a estudiar por la mañana.

\section{5. ¿QUÉ OPORTUNIDADES TE DIERON EN EL CENTRO?}

Solo tenía 3 años para estudiar, porque el forense me dijo que tenía 15 años. Por eso tenía que aprovechar para estudiar, formarme, aprender el idioma.

Cuando acabé el curso me dijeron que obligatoriamente tenía que hacer cursos de formación ocupacional que me dieran diplomas, para poder tener un currículo.

\section{6. ¿HICISTE ALGÚN CURSO DE FORMACIÓN?}

Empecé haciendo jardinería, después hice carpintería en los cursos del Monte $\mathrm{M}^{\mathrm{a}}$ Cristina y después a los 16 años me apunté a un PCPI de Hostelería, de camarero, duraba 1 año casi.

Al pasar ese año me apunté a la escuela de hostelería. Cuando llegaron las prácticas me mandaron a trabajar en el bar "La amistad”, que está en el chiringuito ahora mismo.

\section{7. ¿CONOCÍAS EL IDIOMA? ¿CÓMO LO APRENDISTE?}

No conocía el idioma. Lo aprendí en el centro, por las mañanas hacíamos tareas, además del curso del Enrique Nieto por las tardes.

18. UNA VEZ QUE LLEGAS A MELILLA, ¿CONSUMES ALGÚN TIPO DE DROGA? 
Negativo, no he consumido ningún tipo de droga nunca.

\section{9. ¿¿UÉ CAMBIARÍAS DE TU VIDA EN EL CENTRO?}

A mi lo que no me gustó es que los niños cuando tienen 12, 13 o 14 años, lo mejor que pueden hacer es apuntarlos a estudiar por las mañana. Directamente tienen que estudiar con la gente de Melilla para que se integren y así se puedan sacar sus estudios, su graduado. Si podemos aprovechar y sacarlo, ya empezamos un camino.

Yo por ejemplo estuve estudiando, hice curso de PROMESA, estuve en la Mezquita estudiando, pero con el trabajo no he podido compaginarlo. Los horarios de mi trabajo son incompatibles con los horarios de estudio.

Es muy importante que se saquen sus estudios, mínimo $1^{\circ}$ y $2^{\circ}$ de ESO. Porque así la gente le dan más ganas de estudiar más.

De todo lo demás no cambiaría nada.

\section{0. ¿CÓMO CONSEGUISTE EL TRABAJO?}

Al cumplir los 18 años empecé a trabajar en el chiringuito, en el 2010 y 2011, hasta septiembre de 2012. Ya me conocían por haber hecho las prácticas de hostelería allí. Después me llamaron para hacer la entrevista en la Estación Marítima y aquí estoy trabajando.

\section{1. ¿DÓNDE VIVISTE UNA VEZ QUE CUMPLISTE LA MAYORÍA DE EDAD?}

Una vez que cumplí los 18 años, tenía que esperar un año entero para renovar, porque en Marruecos tenía un año menos, y necesitaba el pasaporte. Así que estuve un año indocumentado, con pasaporte y con todo pero como menor. Y cuando cumplí los 18 años en Marruecos, ya me traje todos los papeles, pasaporte, antecedentes penales, la concordancia, y así me renovaron la documentación.

\section{2. ¿PIENSAS QUE TODOS LOS NIÑOS TENÉIS LAS MISMAS OPORTUNIDADES?}

Depende de la edad, no es lo mismo entrar con 14 o 15 a que tengas 17 años, tienes muy poco tiempo para integrarse y adaptarse. 


\section{3. ¿QUÉ PIENSAS DE OTROS MENORES QUE HAN TENIDO LAS MISMAS OPORTUINIDADES QUE TÚ, PERO NO ESTÁN TRABAJANDO COMO TÚ?}

Cada niño que entrega la Policía Local a La Purísima son iguales, da igual que sea blanco, negro o chino. Lo que pasa que en sus orígenes vienen de unas familias que no han tenido educación suficiente, llegan aquí y siguen igual, el mismo camino por el que iban, un camino malo. Parece una herencia.

Si llegas al centro y te juntas con quien no te debes juntar, no vas a tener posibilidades. Si no aprovechas el tiempo para formarte y poder encontrar un trabajo, obligatoriamente tienes que salir a buscarte la vida, tendrás que robar, entrar como polizón en el barco, para poder conseguir comida.

Si tienes una familia que te ha dado educación te puedes integrar rápido y sino es muy difícil integrarte.

Si no aprovechas el tiempo formándote es muy probable que acabes en la calle.

24. ¿QUÉ CONSIDERAS QUE HA HECHO QUE TENGAS UNA BUENA INSERCIÓN A DIFERENCIA DE OTRAS PERSONAS QUE NO LO CONSIGUEN?

Sobre todo las ganas y la formación, todos los cursos hechos.

\section{5. ¿TIENES CONTACTO CON TU FAMILIA?}

Claro que tengo contacto. Cada 6 meses voy a casa.

En cuanto llegué a la frontera los llamé para decirles que estaba allí y que estaba bien, ese fue el primer contacto desde que salí de casa y nunca he dejado de tener contacto con ellos.

\section{6. ¿CÓMO TE SIENTES EN MELILLA?}

Me siento como en casa, me falta el calor de mi madre, pero que se le va a hacer. Me siento de aquí, aunque me falta mi madre, que viniera ella sería otro problema, porque tendría que hacerle los papeles, pero son pasos muy grandes, hay que escalar mucho. 


\section{7. ¿TE GUSTARÍA VOLVER A TU CASA DE NUEVO?}

Me gustaría volver cuando la tarjeta de crédito esté llena, para retirarme. Para la jubilación.

De momento está bien solo para las vacaciones.

A mi me gusta más Melilla, yo soy de aquí y ahora sería muy difícil cambiar la forma de vida.

28. ¿CUÁLES SON TUS OBJETIVOS? ¿QUÉ QUIERE CONSEGUIR EN EL FUTURO?

Ahora mis objetivos son seguir trabajando y seguir estudiando para poder mejorar en mi trabajo. Además sacarme un curso de administración, poder trabajar en otro sitio que lo pueda compaginar.

29. ¿QUÉ CONSEJO LE DARÍAS A LOS MENORES QUE ESTÁN EN LA CALLE? Lo veo muy complicado, parece que eso está en la sangre, el hecho de no querer integrarse.

Yo en mi trabajo tengo que echarlos en algunas ocasiones de algunas zonas y hablo con ellos y le digo que vayan al centro que tienen oportunidades.

El hecho de que hay personal que pega, es la mayor mentira que he escuchado, entre nosotros sí hay peleas. Hombre si te portas mal te castigan, por ejemplo en mi época te portabas mal y te castigaban sin salir, jamás he visto a nadie poner la mano encima a ningún niño. Yo no entiendo porque estos menores no quieren ir al Centro. Los cuidadores que están allí son casi como nuestros padres.

Estos niños de la calle ya vienen mal de sus casas, a mi se me parte el alma, sobre todo con los más pequeños. Si yo hubiera venido con 9 o 10 años, lo mismo ahora sería profesor de algo, puede ser METOPA, Guardia Civil...te piden muchos requisitos, pero hay que intentarlo hasta que se consigue, a pico y pala. 
- ENTREVISTA 4: Fued, 24.

1. ¿DE DÓNDE ERES?

Soy deOujda.

\section{2. ¿CON QUIÉN VIVÍAS EN TU CASA?}

Vivía en casa con mi madre, mi dos hermanas y mi hermano.

Mis padres se divorciaron y se fue de casa. Yo era muy pequeño, unos 10 u 11 años, me acuerdo de poco, pero sí recuerdo alguna pelea.

\section{3. ¿TU PADRE Y TU MADRE TRABAJAN?¿TRABAJABAN CUANDO TE VINISTE A MELILLA?}

No, mi padre no trabajaba cuando me vine, porque enfermó de un cáncer de próstata y al hacerle la operación no podía trabajar.

Mi madre era ama de casa.

\section{4. ¿CREES QUE TENÍAIS TODO LO NECESARIO PARA VIVIR BIEN? ¿CREES QUE ERA NECESARIO QUE ENTRARA MÁS DINERO EN TU CASA?}

Yo creo que no. Lógicamente yo era pequeño pero no entraba dinero en casa. La familia te ayuda hasta un cierto momento.

\section{1. ¿CÓMO ERA TU CASA? ¿CUÁNTAS HABITACIONES TENÍA?}

Mi casa tenía dos habitaciones, una cocina y un cuarto de baño. De estas casas antiguas de Marruecos que tienen el patio en medio sin techo y las habitaciones alrededor.

\section{5. ¿TE ENCONTRABAS BIEN EN CASA? ¿CÓMO ERA LA RELACIÓN CON} TUS PADRES Y CON TUS HERMANOS? (TENÍAS PROBLEMAS EN CASA). Hombre yo cada vez que voy a mi casa voy a ver a mi padre, pero también entiendo que lo que hizo no estuvo bien. No son manera de dejar a la familia a la deriva, pero entiendo que es mi padre y tengo que quererlo. 
Con mis hermanos la relación es muy buena. Tengo a mi hermana pequeña y mi hermano mayor allí, estamos en contacto y la relación es muy buena.

Antes de venirme también era muy buena la relación.

6. ¿HABÍA UNA BUENA COMUNICACIÓN CON TU FAMILIA, ENTRE TÚ Y TUS PADRES? ¿Y ENTRE TUS PADRES, CÓMO ERA LA RELACIÓN? (VIOLENCIA DE GÉNERO, VIOLENCIA FILIOPARENTAL).

Sí manteníamos una buena comunicación entre mis hermanos y mi madre, aunque es verdad que a mi padre lo veía poco y nunca entendí por qué nos dejó. Pero es mi padre y lo tengo que querer, de vez en cuando iba a verlo. Y cuando voy a mi casa lo veo.

\section{7. ¿EN TU FAMILIA HABÍA ALGÚN TIPO DE CONSUMO (ANTECEDENTE)} DE ALGUNA SUSTANCIA TÓXICA?.

Mi padre sí era consumidor de tabaco y hachís. Aunque una vez que enfermó y lo operaron, dejó el hachís. Hoy día sigue fumando tabaco, aunque en pocas cantidades.

\section{8. ¿QUÉ TE MOTIVÓ PARA VENIR A MELILLA?}

Mi padre se puso malo y no podía trabajar. Le diagnosticaron un cáncer de próstata y lo operaron en Rabat. Mi madre es ama de casa y ese fue el motivo de mi separación con mis padres. Me vine con mi hermana, que estuvo en el centro la Divina Infantita, ahora está en Alemania en Dusseldorf. De hecho voy a verla el 13 del mes que viene que cojo vacaciones.

Yo ya había escuchado esta opción, que tenía la oportunidad de conseguir los papeles y un trabajo. Por eso elegí como destino Melilla.

Me tiré a la aventura. El objetivo era buscar un futuro mejor.

\section{9. ¿CÓMO ORGANIZASTE TU VIAJE?}

Me tiré un verano entero trabajando en un taller, de mecánico de ruedas, y así me hice el pasaporte para poder pasar a Melilla. Entré por la frontera con un hombre que yo no conocía y que se hizo pasar por mi tío. Yo en realidad no entendí nada. 
Me puso en contacto con este hombre el dueño del taller en el que estuve trabajando durante el verano. Este hombre con el que yo pasé era de la zona de Nador, quedamos con él, le dimos toda la documentación y el dinero que nos pidió. Yo saqué el dinero del trabajo que realicé en el taller.

Mi hermana hizo lo mismo que yo, pero un años después. Utilizando el mismo contacto y la misma forma para pasar la frontera.

De Oujda a Nador vine en taxi, tardamos unas dos horas y poco.

\section{0. ¿ CUÁNDO LLEGAS A MELILLA?}

Me vine con lo puesto, recuerdo que era Navidades, un 22 de diciembre de 2005 y recuerdo que llevaba un gorro para el frío, un pantalón, un jersey y los tenis.

\section{CUANDO LLEGASTE A MELILLA ¿QUÉ ES LO PRIMERO QUE HICISTE?}

Lo primero que hice fue dar una vuelta por la zona de la playa, del paseo marítimo, porque además estaba perdido. Melilla era tan diferente a Marruecos que estuve observando.

También di una vuelta por el real y ya me dirigí a la comisaría de la Policía Local.

El hombre que me gestionó la documentación y que me ayudó a pasar, ya me había dicho que fuera directamente allí y que le contara que estaba aquí solo y que solicitara que me llevaran al centro.

\section{2. ¿CONOCÍAS A ALGUIEN QUE HABÍA REALIZADO ESE TRÁMITE?}

No, no conocía a nadie que hubiera hecho este trámite. Toda la información que obtengo es a través de este hombre que me ayuda a realizar los trámites y pasar la frontera.

\section{3. ¿CÓMO LLEGAS AL CENTRO?}

Me dirigí a la comisaría de la Policía Local y allí les expliqué que estaba solo y que me llevaran al centro.

\section{4. ¿CÓMO ES TU VIDA EN EL CENTRO?}

Pues dentro de lo malo....me lo pasé genial. Yo cuando me di cuenta ya tenía 16-17 años. 
Lo que más me gustó fue el hecho de convivir con tanta gente. Acostumbrarte a estar con tantas personas.

No estábamos bien cuidados, porque fuera del módulo sí recibíamos abusos de otros niños mayores. Es cierto que yo no fui víctima de mucho, pero sí que los había.

Tampoco fui un niño problemático e iba a lo mío, tenía muy claro mi objetivo. Después de haberme ido de casa, era para tener un futuro y aquí tenía la oportunidad.

\section{5. ¿QUÉ OPORTUNIDADES TE DIERON EN EL CENTRO?}

El centro me dio la oportunidad de conseguir mi futuro. Me enseñaron a estudiar, hice un viaje de campamento.

\section{6. ¿HICISTE ALGÚN CURSO DE FORMACIÓN?}

Estuve hasta $3^{\circ}$ de la ESO. Hice un curso de hostelería de cocina y sala. Hice carpintería. Los dos primeros años hice un curso de apoyo. Además se me daba bien, no sacaba unas notas muy altas, pero se me daba bien.

\section{7. ¿CONOCÍAS EL IDIOMA? ¿CÓMO LO APRENDISTE?}

El idioma no tenía ni idea. Aprendí en el centro, ellos me dieron la oportunidad y yo la aproveché, el tren pasa una vez.

18. UNA VEZ QUE LLEGAS A MELILLA, ¿CONSUMES ALGÚN TIPO DE DROGA?

Sí, estando en el centro si probé el hachís y el pegamento en un tiempo. No mantuve el consumo, solo fue por probar.

Estando en el centro con los niños es difícil no probar ningún tipo de sustancia. Además las circunstancias eran difíciles, yo sufrí algún abuso de los niños mayores del centro, y ese hecho no es que me empujó a consumir, pero sí que me refugié en esas sustancias pensando que me ayudaban. Ten en cuenta que cuando venimos no tenemos ningún apoyo familiar que te guíe, que te de consejos y el cariño. Lo pagas con cualquier cosa. 


\section{9. ¿QUÉ CAMBIARÍAS DE TU VIDA EN EL CENTRO?}

No, no cambiaría nada del centro.

\section{0. ¿CÓMO CONSEGUISTE EL TRABAJO?}

El primer trabajo fue porque hice las prácticas de la escuela de hostelería y allí me quedé trabajando.

\section{1. ¿DÓNDE VIVISTE UNA VEZ QUE CUMPLISTE LA MAYORÍA DE EDAD?}

Yo no tuve ningún problema porque conseguí el trabajo después de las prácticas y la documentación me la dieron en el centro. Yo salí de allí con mi documentación con una duración de una año, aunque no me autorizaba a trabajar, pero mi primer jefe fue el que me ayudó a cambiarla para que me autorizara a trabajar. A través del contrato de trabajo me dieron la residencia de los cinco años.

En cuanto a la vivienda no tuve problema. Al principio me echó una mano mi jefe, tuve muchísima suerte en conocer a esa persona y otras que me he ido encontrando a lo largo de mi vida. Fue él el que me consiguió vivir en la residencia de estudiantes durante dos o tres años, sin nada a cambio.

\section{2. ¿PIENSAS QUE TODOS LOS NIÑOS TENÉIS LAS MISMAS OPORTUNIDADES?}

Sí, todos somos iguales, lo importante es aprovechar las oportunidades que te ofrecen.

\section{3. ¿QUÉ PIENSAS DE OTROS MENORES QUE HAN TENIDO LAS MISMAS OPORTUINIDADES QUE TÚ, PERO NO ESTÁN TRABAJANDO COMO TÚ?}

Me dan mucha pena estos niños, porque yo he pasado por lo que están pasando, aunque yo nunca estuve en la calle. Cuando hablas con ellos, parece que le tienen la cabeza comida, parece que en la calle lo tienen todo y todo fácil y no es así. Intentas hablar con ellos y le explicas en qué situación estoy y le digo que lo aprovechen, que el tren en esta vida pasa una vez, como digo yo. 
Piensan que se van a colar y que van a llegar a la Península y van a tenerlo todo fácil y que va lo tienen hasta más difícil. Yo creo que lo tienen más fácil desde Melilla, conseguir los papeles, un trabajo...pero se encabezonan y esa es la cuestión.

\section{4. ¿QUÉ CONSIDERAS QUE HA HECHO QUE TENGAS UNA BUENA INSERCIÓN A DIFERENCIA DE OTRAS PERSONAS QUE NO LO CONSIGUEN?}

Yo también me lo he merecido, lo he trabajado, me he ganado la confianza. Los niños que no aprovechan estas oportunidades son porque se tiran a la calle, se tiran a las drogas, el pegamento. No se dejan aconsejar y se dejan llevar por gente que no le da buenos consejos.

Aquí tienen muchísimas opciones de trabajar, de estudiar, de aprender y no lo aprovechan.

No creo que influya de dónde eres. Todos convivíamos en el centro.

La edad a la que vengas sí es muy importante. Yo vine a los 12 años. Porque a partir de los 16 años ya es muy difícil que te metan en una clase o que vayas al colegio a estudiar. Cuanto más pequeño mejor.

\section{5. ¿TIENES CONTACTO CON TU FAMILIA?}

Desde que llegué a Melilla estuve en contacto con mi familia, en concreto con mi madre. Antes la llamaba poco porque no disponíamos de dinero, en aquellos tiempos era muy difícil tener dinero, pero de vez en cuando manteníamos esa conversación; “hola ¿qué tal?, estoy bien, como bien, duermo bien”; eso es lo que más le interesaba.

Fui a casa, que me llevó mi jefe, con el que trabajaba aquí en Melilla. Estaba muy ilusionado, llevaba cinco años sin ir a mi casa y no me acordaba de mi casa. Una anécdota es que no me acordaba del camino de mi casa, y en vez de ir para mi casa nos fuimos hacia la frontera de Argelia, y no me di cuenta hasta que comencé a ver los controles. Tuve que llamar a mi hermano que vino a por nosotros y nos llevó a mi casa.

\section{6. ¿CÓMO TE SIENTES EN MELILLA?}

Me siento como uno más. Estoy muy cómodo, aunque me gustaría irme a la Península. 


\section{7. ¿TE GUSTARÍA VOLVER A TU CASA DE NUEVO?}

No, lo tengo muy claro.

28. ¿CUÁLES SON TUS OBJETIVOS? ¿QUÉ QUIERE CONSEGUIR EN EL FUTURO?

Quiero ir a la Península, me gustaría. Llevo en Melilla muchos años y me gustaría cambiar. Yo estuve trabajando en Málaga, pero me vine porque echaba de menos a Melilla, pero principalmente porque mi novia estaba aquí estudiando. Una vez que me vine a Melilla, a ella le dieron el traslado fuera y ahora está estudiando en Almería, ese motivo también me empuja para querer irme.

29. ¿¿UÉ CONSEJO LE DARÍAS A LOS MENORES QUE ESTÁN EN LA CALLE? Yo cuando veo a los menores de la calle se lo digo, lo tenéis todo, le explico mi situación, he estudiado, he viajado de campamento...que aprovechen la oportunidad, que no la dejen pasar que el tiempo pasa muy rápido.

- ENTREVISTA 5: Ali, 19.

1. ¿DE DÓNDE ERES?

Soy de Marruecos, de la parte "El-Yadida” -detrás de Casa Blanca-. Tengo 19 años.

2. ¿CON QUIÉN VIVÍAS EN TU CASA?

Yo vivía con mi abuela y un hermano pequeño.

3. ¿TU PADRE Y TU MADRE TRABAJAN?¿TRABAJABAN CUANDO TE VINISTE A MELILLA?

Mi madre murió en un accidente. Cuando esto sucedió, mi padre me dejó con mi abuela y el se fue.

4. ¿CREES QUE TENÍAIS TODO LO NECESARIO PARA VIVIR BIEN? ¿CREES QUE ERA NECESARIO QUE ENTRARA MÁS DINERO EN TU CASA?

Teníamos comida, teníamos ropa, pero no teníamos futuro, yo porque era pobre, no podía estudiar, si estudiaba quién iba a trabajar para mí, mi abuela estaba un poco vieja y aunque 
se buscaba la vida, vendiendo la fruta y verdura que recolectaba. También teníamos una vaca, pero era yo el que tenía que trabajar para mi abuela y mi hermano pequeño.

Dejé el colegio y me puse a trabajar a los 7 años.

5. ¿TE ENCONTRABAS BIEN EN CASA? ¿CÓMO ERA LA RELACIÓN CON TUS PADRES Y CON TUS HERMANOS? (TENÍAS PROBLEMAS EN CASA). Manteníamos buena comunicación con mi abuela y mi hermano. No teníamos ningún problema en casa, estábamos tranquilos.

El único problema fue que teníamos poco dinero en casa, pero nada más.

6. ¿HABÍA UNA BUENA COMUNICACIÓN CON TU FAMILIA, ENTRE TÚ Y TUS PADRES? ¿Y ENTRE TUS PADRES, CÓMO ERA LA RELACIÓN? (VIOLENCIA DE GÉNERO, VIOLENCIA FILIOPARENTAL).

Yo me críe con mi abuela y la relación era muy buena.

\section{7. ¿EN TU FAMILIA HABÍA ALGÚN TIPO DE CONSUMO (ANTECEDENTE) DE ALGUNA SUSTANCIA TÓXICA?.}

No, ningún familiar que consuma. Tengo un tío pero era sano, deportista, es campeón de Marruecos de pesas.

\section{8. ¿QUÉ TE MOTIVÓ PARA VENIR A MELILLA?}

Estuve hablando con un amigo mío, que me comentó que podíamos cambiar la vida, que podríamos tener un futuro, un trabajo.

Yo no había escuchado hablar de Melilla, no sabía que existía. Aunque mi amigo sí. Pero yo al vivir en el campo no tenía esa información.

Pensé que podía hacer algo y ganar algo con el Atletismo aquí.

9. ¿CÓMO ORGANIZASTE TU VIAJE?

Directamente me vine a Melilla, sin hablar con nadie. No se lo dije a mi abuela. 
Pensé que tenía que buscar un trabajo bueno y mejorar la vida.

Antes de venir a Melilla, me fui a trabajar un mes con un hombre a una tienda. Yo llevo trabajando desde los 7 años, vendiendo verdura, fruta, en el zoco. Tenía guardado algo de dinero para el atletismo, porque yo corría en Marruecos también.

Cuando pensé en venir aquí cogí 250€, del dinero que tenía guardado para el atletismo.

Yo no conocía a nadie ni sabía nada. No preparé ningún tipo de documentación, ni me puse en contacto con nadie antes de venir.

\section{0. ¿ CUÁNDO LLEGAS A MELILLA?}

Hace dos años que llegué aquí.

\section{CUANDO LLEGASTE A MELILLA ¿QUÉ ES LO PRIMERO QUE HICISTE?}

Lo primero es buscar un sitio para comer, un sitio para dormir. Con $200 €$ que me quedaban, porque me gasté $50 €$ en el viaje, no puedes pagar nada, es muy difícil para vivir aquí en Melilla.

Yo no sabía que había un centro donde los niños pueden quedarse, comer, dormir...Yo lo primero que hice fue quedarme en la calle, y allí me encontré con muchos niños. Ellos me hablaron del centro, aunque me hablaron del centro de forma negativa, hablaron mal, decían que no se podía salir, que había que cumplir horarios...la verdad que tenía miedo de ir al centro.

Antes de entrar en el centro cometí un delito, un robo. Un chaval de la calle me llenó mi cabeza y cogí una cosa que no era mía. La policía me pilló y fueron ellos los que me llevaron al centro.

Pasé por el juzgado por este delito, pero estuve hablando con el abogado y le expliqué, que lo había hecho porque no tenía qué comer.

\section{2. ¿CONOCÍAS A ALGUIEN QUE HABÍA REALIZADO ESE TRÁMITE?}

No conocía a nadie que hubiera estado en el centro. 


\section{3. ¿CÓMO LLEGAS AL CENTRO?}

Llegué al centro porque la policía me pilla al cometer un robo y son ellos los que me llevan al centro.

\section{4. ¿CÓMO ES TU VIDA EN EL CENTRO?}

Estuve en el centro muy bien. El centro es otro mundo a lo que los niños estaban hablando, no tenía nada que ver.

Me levantaba por la mañana, pensé en volver al atletismo, así que salía por la mañana para entrenar, volvía y me aseaba, arreglaba mis cosas y por las tardes me iba otra vez a entrenar.

\section{5. ¿QUÉ OPORTUNIDADES TE DIERON EN EL CENTRO?}

La Purísima a mí me ha ayudado mucho, tuve donde dormir, donde comer, me podía duchar, me dieron ropa. Me ayudaron mucho para conseguir los papeles, dándome toda la información, las gestiones las hice yo, con ayuda de más personas, pero desde el centro me dieron la información.

Además me pusieron en contacto con un club de atletismo e iba a entrenar a las pistas.

\section{6. ¿HICISTE ALGÚN CURSO DE FORMACIÓN?}

Estudié durante 3 meses en el centro del Monte $\mathrm{M}^{\mathrm{a}}$ Cristina, aprendiendo español, alfabetización.

\section{7. ¿CONOCÍAS EL IDIOMA? ¿CÓMO LO APRENDISTE?}

Cuando llegué no conocía nada del idioma. Gracias a Purísima y ahora al trabajo, he aprendido a hablar español.

Estuve en el centro un año y cuatro meses y gracias a eso aprendí el idioma. Anteriormente estuvo unos siete meses en la calle.

Mi vida en la calle fue muy difícil, además fue en el tiempo de lluvia y de frío. 
18. UNA VEZ QUE LLEGAS A MELILLA, ¿CONSUMES ALGÚN TIPO DE DROGA?

No, nunca metí mi mano ahí. Ni siquiera el tiempo que estuve en la calle.

Lo único que hice malo fue coger eso que no era mío, porque me dejé llevar por otros niños, pero nunca hice nada más. Los niños que son buenos, son buenos.

El tiempo que estuve en la calle también estaba entrenando, eso me ayudó a no meterme en nada de drogas. No sabía que existían unas pistas ni equipos, porque no conocía nada, pero corría por las calles de Melilla, entrenaba solo.

\section{9. ¿QUÉ CAMBIARÍAS DE TU VIDA EN EL CENTRO?}

Estuve viviendo en la calle...en La Purísima...todo está bien. Y la gente, hay que pasar de ellos. Si estuviera en mi casa, podría tener un vecino con el que no estoy bien. En Purísima éramos 6 niños en la habitación, pues como en todos sitios, hay algunos buenos, algunos malos, algunos consumen pegamento están un poco nerviosos, pero tienes que pasar de la gente.

Con los educadores no tengo ningún problema, todos me han dado confianza, se han portado muy bien conmigo. Cuando me faltaba alguna cosa me preguntaban, me enseñaron las pistas de atletismo, algunos me han comprado tenis, otros me han comprado chándal, ropa, un vigilante también me trajo ropa, me dieron buenos consejos. Todos me han ayudado mucho.

\section{0. ¿CÓMO CONSEGUISTE EL TRABAJO?}

Consigo el trabajo a través de mi entrenador de atletismo y su mujer. Ellos son como mis padres.

\section{1. ¿DÓNDE VIVISTE UNA VEZ QUE CUMPLISTE LA MAYORÍA DE EDAD?}

En Marruecos mi padre no me arregló ningún papel, así que no tenía pasaporte ni nada. Cuando llegué y cumplí la mayoría de edad y pensé en trabajar, me ayudó mi entrenador y su mujer, también más gente que me ayudaron a arreglar todos los papeles. Estas personas son como mis padres. 
Cuando cumplí la mayoría de edad y salí del centro, me buscaron un trabajo en CLECE. Fui a Marruecos a arreglar mis papeles.

Yo no salí del centro con mi documentación. Cuando salí estuve viviendo en la residencia de estudiantes, porque me lo facilitó la Consejería.

\section{2. ¿PIENSAS QUE TODOS LOS NIÑOS TENÉIS LAS MISMAS OPORTUNIDADES?}

Para poder conseguir algo tienes que sufrir por ello, tienes que trabajar por ello.

Tengo muchos amigos que han conseguido la documentación y ahora están fuera de Melilla.

\section{3. ¿QUÉ PIENSAS DE OTROS MENORES QUE HAN TENIDO LAS MISMAS OPORTUINIDADES QUE TÚ, PERO NO ESTÁN TRABAJANDO COMO TÚ?}

Tuve miedo al pensar que había niños que cogían la documentación y otros no.

Otros niños no consiguen sus papeles porque no se portan bien, hacen muchas tonterías, duermen en la calle y no se portan bien, roba, tiene peleas, así es normal que no consiga la documentación.

\section{4. ¿QUÉ CONSIDERAS QUE HA HECHO QUE TENGAS UNA BUENA INSERCIÓN A DIFERENCIA DE OTRAS PERSONAS QUE NO LO CONSIGUEN?}

Yo he trabajado y sufrido mucho por mi documentación. Me portaba bien, hacía deporte y he ganado muchas carreras, no he tenido problemas en el centro, he seguido las normas, los horarios, no he tenido peleas en el centro, no darte de baja -todas las noches tienes que dormir en el centro-.

\section{5. ¿TIENES CONTACTO CON TU FAMILIA?}

Sí, tengo contacto con mi abuela. Cuando llegué a Melilla no la llamé, porque estaba en la calle. Cuando entré al centro, un amigo tenía un móvil y la llamé. 
El amigo con el que hice el viaje a Melilla volvió a su casa. Él tenía a sus padres que estaban trabajando, no tenía necesidad y no aguantó estar en la calle.

Yo no tenía ningún motivo para volver, al contrario yo tenía que trabajar para mi abuela.

\section{6. ¿CÓMO TE SIENTES EN MELILLA?}

Yo estoy muy bien, conozco a mucha gente, tengo compañeros de trabajo, conozco a mis compañeros del atletismo. Estoy contento y cómodo. Como en todos sitios hay gente buena y gente mala, pero no pasa nada, hay que pasar de ellos.

\section{7. ¿TE GUSTARÍA VOLVER A TU CASA DE NUEVO?}

No, esto es otro mundo. Tengo trabajo, ahora estoy trabajando en limpieza en el CETI.

\section{8. ¿CUÁLES SON TUS OBJETIVOS? ¿QUÉ QUIERE CONSEGUIR EN EL FUTURO?}

Ahora mismo estoy lesionado de la rodilla, ahora estoy pensando en seguir preparando una carrera, 1.500 o 5.000 metros. Mejorar en el trabajo. Pero me gustaría ser un campeón de España en atletismo.

También pienso en casarme y formar una familia, pero ahora mismo soy muy joven, aunque yo ya pienso en el futuro.

Me gustaría quedarme en Melilla, aquí tengo una familia, mi entrenador y su mujer y ahora no los puedo dejar.

\section{9. ¿QUIERES AÑADIR ALGO MÁS?}

Me gustaría agradecer a todo el mundo que me ha ayudado. Conozco gente que ha estado en Melilla 5 años y no han conseguido los papeles. A mi me han ayudado a conseguirlos y me gustaría agradecérselo a todos los que me han ayudado.

\section{0. ¿QUÉ LE DIRÍAS A ESOS NIÑOS QUE ESTÁN EN LA CALLE?}

Mira para ganar dinero hay que trabajar. Pues para conseguir los papeles también. Si no haces cursos, robas, fumas, te peleas, es normal que no consigas papeles. 
He hablado con un amigo mío que está en la calle y él me dice que tenía liada la cabeza, que estaba tonto y ahora llora; yo le digo que tenía que haber llorado antes, ahora no sirve, ahora es mayor.

- ENTREVISTA 6: Brahim, 19.

1. ¿DE DÓNDE ERES?

Soy de Nador.

\section{2. ¿CON QUIÉN VIVÍAS EN TU CASA?}

Yo vivía con mis padres y mi hermana pequeña.

3. ¿TU PADRE Y TU MADRE TRABAJAN?¿̇RABAJABAN CUANDO TE VINISTE A MELILLA?

Sí, mi padre trabajaba aquí en Melilla en el tema de contrabando.

\section{4. ¿CREES QUE TENÍAIS TODO LO NECESARIO PARA VIVIR BIEN? ¿CREES QUE ERA NECESARIO QUE ENTRARA MÁS DINERO EN TU CASA}

La familia sí. Pero lo que yo quería hacer no. A mi me gustaba el fútbol desde pequeño y me quería dedicar a ello. Entonces me comentaron que en Melilla había un centro en el que podría ingresar a estudiar y a jugar a fútbol.

No éramos ricos, pero llegábamos bien a fin de mes. Éramos una familia humilde.

Nosotros alquilábamos, no teníamos una casa en propiedad. Primero vivíamos en Mekness, que tenía dos cuartos pequeños, la cocina y un comedor, y mi hermana y yo dormíamos en el cuarto pequeño y mis padres en el cuarto grande.

Cuando llegamos a Nador sí que teníamos una casa en propiedad que era grande, pero mi padre tuvo un problema con un hombre y la tuvimos que venderla.

Todas las casas en las que hemos vivido han sido aproximadamente igual. 


\section{5. ¿TE ENCONTRABAS BIEN EN CASA? ¿CÓMO ERA LA RELACIÓN CON TUS PADRES Y CON TUS HERMANOS? (TENÍAS PROBLEMAS EN CASA).}

Sí la verdad que sí, estaba muy a gusto. Primero en Mekness que también hacía judo y luego en Nador seguí estudiando y jugando al fútbol, lo que pasa que en Marruecos no te puedes apuntar a un equipo.

La relación con mis padres bien la verdad. Éramos una familia humilde pero bien. Lo que pasa que yo era muy pequeño, yo vine aquí con 5 o 6 años.

6. ¿HABÍA UNA BUENA COMUNICACIÓN CON TU FAMILIA, ENTRE TÚ Y TUS PADRES? ¿Y ENTRE TUS PADRES, CÓMO ERA LA RELACIÓN? (VIOLENCIA DE GÉNERO, VIOLENCIA FILIOPARENTAL).

La comunicación con mi familia muy buena, aunque yo era muy pequeño. Me regañaban con frecuencia porque era muy revoltoso pero muy bien.

En Marruecos las familias son distintas, porque se meten mucho los abuelos, las abuelas, entonces había problemas con estos miembros de la familia, pero entre mis padres y mis padres conmigo y con mi hermana y otro más que nació después muy bien.

7. ¿EN TU FAMILIA HABÍA ALGÚN TIPO DE CONSUMO (ANTECEDENTE) DE ALGUNA SUSTANCIA TÓXICA?.

Mi padre bebía, pero cuando yo ingresé en el centro lo dejó. El resto de mi familia no tenía ningún vicio.

8. ¿QUÉ TE MOTIVÓ PARA VENIR A MELILLA?

Porque yo quería venir para jugar al fútbol.

Un amigo de mi padre le explicó que estaba esta posibilidad, venir a un centro de Melilla que me darían la oportunidad de estudiar y que iba a estar bien.

Mi padre me lo comentó a mi me pareció bien y a él también y por eso vine.

9. ¿CÓMO ORGANIZASTE TU VIAJE?

A mi me trajeron mis padres a Melilla, yo entré con mi pasaporte. 
Me dijeron que tenía que ir a la Policía Local, ellos te preguntan pero tu no sabes hablar español ni nada, así que piensan que es un niño que lo han abandonado o no puede vivir con sus padres por lo que sea y me trasladaron al centro directamente.

La decisión fue mía porque yo quería irme para poder jugar al fútbol, pero fue complicado porque mi madre no quería, aunque al final accedió.

10. ¿ CUÁNDO LLEGAS A MELILLA?

Llegué cuando tenía 5 o 6 años. Ahora tengo 19 años.

\section{CUANDO LLEGASTE A MELILLA ¿QUÉ ES LO PRIMERO QUE HICISTE?}

Yo pase con mis padres la frontera. Ya nos habían dicho que teníamos que dirigirnos a la Policía Local, así lo hice y me llevaron al centro directamente.

\section{2. ¿CONOCÍAS A ALGUIEN QUE HABÍA REALIZADO ESE TRÁMITE?}

Sí, yo tengo un hermano mayor por parte de padre que estuvo en un centro aquí en Melilla. Estaba en el centro "Hogar del Puerto". Y habló con mi padre para que pudiera jugar al fútbol y estudiar.

\section{3. ¿CÓMO LLEGAS AL CENTRO?}

Ya nos habían dicho que teníamos que ir directamente a la Policía Local y de ahí ellos me llevaron al centro. Nosotros conocíamos los pasos que teníamos que dar.

Yo tengo ahora 19 años.

\section{4. ¿CÓMO ES TU VIDA EN EL CENTRO?}

Cuando llevaba tres meses, mi madre no podía estar sin mi y vino a la Consejería y me recogió del centro y volví a mi casa. Pero le dijeron a mi madre que yo estaba bien en el centro, que podía tener un futuro mejor y entonces al poco tiempo, 15 días, volví.

Es un cambio, es un chock, porque de estar viviendo con cuatro personas en la casa a vivir con 20 personas, me quedé muy sorprendido de que todo se movía aquí rápido, además la cultura era diferente. Además cuando viene un niño nuevo le suelen molestar. Hay que 
tener en cuenta que a mí no me metieron en el Pabellón con los niños pequeños, me metieron directamente con los niños mayores.

Siempre he dicho que esto me ha venido mejor, porque así maduré muy pronto.

Nunca tuve ningún problema en el centro, todo muy bien.

\section{5. ¿QUÉ OPORTUNIDADES TE DIERON EN EL CENTRO?}

Me ha dado todas a nivel de formación, aunque a nivel profesional, que me dedico a jugar al fútbol me lo he buscado yo, me lo ha dado mis pies. Me saqué la ESO y ahora quiero seguir estudiando porque el fútbol es una vida corta, hasta los 35 o los 36 años.

\section{6. ¿HICISTE ALGÚN CURSO DE FORMACIÓN?}

Me saqué la ESO y ya me fui a Almería. Estuve haciendo $1^{\text {o }}$ de Bachillerato pero lo dejé. Hice un curso profesional de mecánica, aunque no me acuerdo bien.

\section{7. ¿CONOCÍAS EL IDIOMA? ¿CÓMO LO APRENDISTE?}

No conocía bien el idioma, pero me ayudó mucho el centro.

18. UNA VEZ QUE LLEGAS A MELILLA, ¿CONSUMES ALGÚN TIPO DE DROGA?

No, nunca. Me han ofrecido, pero yo desde pequeño he tenido siempre mucha personalidad, nunca probé nada ni alcohol, tabaco, ni nada.

\section{9. ¿QUÉ CAMBIARÍAS DE TU VIDA EN EL CENTRO?}

No cambiaría nada del centro. Siempre digo que una de las mejores cosas que me han pasado en mi vida es haber pasado por el centro.

Cambiaría el horario estricto de la cocina, si no llegas a tu hora ya no puedes comer y eso en una casa no pasa, puedes comer a la hora que tú quieras. Por lo menos alargar algo el horario de comida. 
Desde los 7 años estoy jugando al fútbol, y me vio un entrenador que también trabaja en la Gota de Leche y le gusté y me fichó para su equipo y desde ahí empecé a destacar y cuando tuve 17 años me fichó la UD Almería y ahora he vuelto a Melilla porque tengo contrato con la UD Melilla.

A Almería me voy siendo menor de edad, por lo que me voy como si fuera de vacaciones y cumplo la mayoría de edad en Almería.

Yo con el tema de la documentación no tuve que hacer ningún trámite porque a mi me dieron la documentación permanente y no tuve que hacer ningún trámite.

\section{1. ¿DÓNDE VIVISTE UNA VEZ QUE CUMPLISTE LA MAYORÍA DE EDAD?}

Directamente me ficharon siendo menor y me fui fuera a Almería y vivía allí. No tuve problema para conseguir vivienda.

\section{2. ¿PIENSAS QUE TODOS LOS NIÑOS TENÉIS LAS MISMAS OPORTUNIDADES?}

Si nos la buscamos nosotros sí. Si tú te portas bien, por ejemplo, si tienes un jefe y le caes bien como tú eres, claro que vas a tener oportunidades. Ahora si eres gamberro y la lías por donde tú vas, no vas a tener ninguna oportunidad. Eso depende de cada uno.

\section{3. ¿QUÉ PIENSAS DE OTROS MENORES QUE HAN TENIDO LAS MISMAS OPORTUINIDADES QUE TÚ, PERO NO ESTÁN TRABAJANDO COMO TÚ?} Porque no han estado centrados y con sus ideas claras y se han dejado llevar por malos consejos. Si persigues tus objetivos puedes conseguirlo.

\section{4. ¿QUÉ CONSIDERAS QUE HA HECHO QUE TENGAS UNA BUENA INSERCIÓN A DIFERENCIA DE OTRAS PERSONAS QUE NO LO CONSIGUEN?}

Tienes que tener la cabeza centrada cuando llegas al centro. Si tienes la mentalidad de robar, estar en la calle. Ahora si tienes la cabeza centrada y persigues lo que quieres, lo conseguirás, como yo, que quería ser futbolista y ahora lo soy. Hay otros que querían ser camareros o jefes de cocina y ahora lo son. 
Tienes que tener personalidad. Porque un niño puede venir bien, pero viene otro nuevo y le dice cualquier cosa y ya lo desvía y ya lo lleva por mal camino.

Hay que tener personalidad, estar centrado e ir por lo que quieres.

\section{5. ¿TIENES CONTACTO CON TU FAMILIA?}

Sí claro. De hecho ahora estoy pasando las vacaciones de Ramadán con ellos, porque si me quedo aquí me voy a morir de hambre, porque yo no sé cocinar.

\section{6. ¿CÓMO TE SIENTES EN MELILLA?}

Me siento bien. Cuando me fui a Almería, estuve allí un año entero y no vine en todo el año y estaba deseando venir. Es una Ciudad que la echas mucho de menos cuando te vas. Yo no te voy a mentir, yo he llorado estando fuera, por la familia, por los amigos, por muchas cosas.

La gente me ha acogida bien. Han visto que era pequeño, simpático y me querían incluso cambiar el nombre, me querían poner José, porque vine muy pequeño, pero no quise cambiarme el nombre.

Aquí hay otra cultura, por ejemplo, si tu vas por Marruecos con unos vaqueros rotos o tenis de colores, te miran raro, sin embargo aquí en Melilla o en Madrid si vas así vestido no llamas la atención. En Marruecos tienen la mente más cerrada. Yo prefiero la cultura europea, la cultura de Melilla.

\section{7. ¿TE GUSTARÍA VOLVER A TU CASA DE NUEVO?}

Sí, no me importaría. Depende de la profesión, como yo me dedico al fútbol, yo vivo donde juegue, no donde yo quiera. Por eso si juego en Marruecos, traslado a mi familia a Marruecos.

28. ¿CUÁLES SON TUS OBJETIVOS? ¿QUÉ QUIERE CONSEGUIR EN EL FUTURO?

A nivel personal mi objetivo es conseguir la nacionalidad, porque así me quito de problemas, porque al viajar te miran un poco raro y así me quitaría ese problema. 
Dentro de poco me voy a casar con mi novia.

Poder promocionar en el fútbol, ahora mismo estoy en un equipo de $2^{\mathrm{a}} \mathrm{B}$ y me gustaría poder llegar a $1^{\mathrm{a}}$.

Quiero comprarme una casa, un coche.

Con el fútbol se vive bien, le puedes comprar una casa a tus padres, comprártela tú.

Yo desde los 15 años ayudo a mis padres económicamente, ellos trabajan un poco y yo les ayudo otro poco.

Cuando estuve en Almería jugando, les daba el $40 \%$ de mi sueldo y en Melilla le daba el $50 \%$ de mis sueldo. Ahora le doy entre el $45-30 \%$ de mi sueldo y bien, se puede vivir bien con eso.

\section{9. ¿QUÉ LE DIRÍAS A LOS NIÑOS QUE ESTÁN EN LA CALLE SI TUVIERAS}

\section{LA OPORTUNIDAD?}

Le diría que fueran al centro, pero ahora como están las cosas no ingresas directamente en Gota de Leche y a ellos no les gusta La Purísima, por eso hay muchos niños en la calle.

No les gusta La Purísima, porque hay 400 niños y hay niños por ejemplo que tienen en Marruecos 25 años y vienen aquí con la documentación falsificada y le ponen 17 años y abusan de ellos.

A mi me han comentado cosas, no se si será verdad, que los educadores les pegan a los niños. Entonces un niño viene de Marruecos con 6 o 7 años ve eso, y piensa que es mejor irse a la calle o intentar colarse en el barco.

\section{0. ¿QUIERES AÑADIR ALGO MÁS?}

Me da pena que generalicen a todos los chavales. Sí es cierto que hay algunos malos, pero no tienen que generalizar. 
- ENTREVISTA 7: Neyi, 27.

1. ¿DE DÓNDE ERES?

Soy de Fez.

\section{2. ¿CON QUIÉN VIVÍAS EN TU CASA?}

Vivía con mis abuelas. Ellas vivían en el mismo edificio, una en el primero y la otra en el segundo y yo estaba entre las dos casas.

Mis padres se separaron cuando yo tenía 4 años, mi padre se fue a Mekness y mi madre se fue a Tánger a trabajar y yo me quedé con mis abuelas.

Soy hijo único.

En casa de mi abuela materna estaban mis tíos, una de mis tías tenía mi edad, así que crecimos como hermanos. Eran tres tías y tres tíos.

En la casa de mi abuela paterna estaba sola en casa.

3. ¿TU PADRE Y TU MADRE TRABAJAN?¿TRABAJABAN CUANDO TE VINISTE A MELILLA?

Mi padre se casó dos o tres veces más. Hace dos años se volvió a casar y tiene una hija de dos años. Mi padre era militar, aunque se escapó y no lo terminó. Y en este tiempo se ha dedicado a todo, trabajaba en lo que podía. Él no nos mandaba nada de dinero. Sólo venía a verme de vez en cuando.

Mi madre se volvió a casar hace poco. Sí mi madre trabajaba en una fábrica de ropa, ahora es jefa de control en la misma fábrica.

4. ¿CREES QUE TENÍAIS TODO LO NECESARIO PARA VIVIR BIEN? ¿CREES QUE ERA NECESARIO QUE ENTRARA MÁS DINERO EN TU CASA?

Sólo me faltaba el cariño de mi madre. 
Yo no vivía mal, estaba muy bien. No faltaba nada a nivel económico. Mi madre nos mandaba dinero y no nos faltaba de nada.

Mi madre venía dos o tres veces al año, para las fiestas. Una vez que cumplí los 15 años, me dejaban viajar solo y podía ir a Tánger a verla.

\section{5. ¿TE ENCONTRABAS BIEN EN CASA? ¿CÓMO ERA LA RELACIÓN CON TUS PADRES Y CON TUS HERMANOS? (TENÍAS PROBLEMAS EN CASA).}

La relación con mis abuelas era muy buena. Hombre me regañaban alguna vez, pero muy poco. Era el único nieto y era pequeño, entonces eran muy agradable conmigo. Le contaba las cosas y todo muy bien.

La relación con mis tíos también era muy buena. Me peleaba en alguna ocasión con mi tía pequeña, la que tenía mi edad, por cosas de la casa...lo normal entre hermanos.

6. ¿HABÍA UNA BUENA COMUNICACIÓN CON TU FAMILIA, ENTRE TÚ Y TUS PADRES? ¿Y ENTRE TUS PADRES, CÓMO ERA LA RELACIÓN? (VIOLENCIA DE GÉNERO, VIOLENCIA FILIOPARENTAL).

Con mis padres no tenía una comunicación diaria porque vivían fuera. Con mis abuelas y mis tíos la relación era muy agradable y estábamos muy bien en casa.

\section{7. ¿EN TU FAMILIA HABÍA ALGÚN TIPO DE CONSUMO (ANTECEDENTE) DE ALGUNA SUSTANCIA TÓXICA?.}

No, nadie de mi familia consumía ningún tipo de droga. Además si no llegaba a las 22:00 a casa ya salían a buscarme y me regañaban.

Teníamos una tía que estaba mala, estaba poseída, tenía demonios dentro, y por eso tomaba medicación. Algunas veces hacía cosas raras pero se le pasaba.

\section{8. ¿QUÉ TE MOTIVÓ PARA VENIR A MELILLA?}

Una vez que me dejaron viajar solo y pude ir a ver a mi madre, al año siguiente me mandaron a Beni Enzar de vacaciones con una tía. Cuando llegué a casa de mi tía, pregunté por mi primo y me dijeron que estaba en Melilla. Al preguntar qué hacía allí, ya me 
explicaron que había un centro y que estaba allí para poder conseguir la documentación y un futuro mejor.

Después de esas vacaciones volví a mi casa y le conté a mi madre dónde estaba mi primo. Estaba en un centro de menores, donde lo mantenían, le daban estudios y todo eso. Mi madre me dijo que no me dejaba irme. Que a mí no me faltaba de nada, que para eso ella estaba trabajando, que si me faltaba algo se lo dijera a ella que ella me lo daba.

Ves un futuro mejor, te llenan la cabeza de ideas de que vas a estar mejor, aunque tú vivas bien, te dicen que vas a tener un trabajo mejor, puedes aprender el idioma, estudiar...y por probar.

\section{9. ¿CÓMO ORGANIZASTE TU VIAJE?}

Pasaron dos meses, desde que le había comentado a mi madre el tema de venirme a Melilla y tuve una discusión con mi tío y me pegó, encontré la escusa de escaparme de casa. Me fui directamente a Mekness a casa de mi padre y le dije que me había pegado mi tío y que yo lo que quería era irme a Melilla con mi primo y mi padre me trajo para acá.

\section{0. ¿ CUÁNDO LLEGAS A MELILLA?}

Estaba en vacaciones del colegio y vine a probar, si no me gustaba volvía a casa. Y cuando entré me gustó, así que me quedé.

Vine solo a Melilla. Con 15 años. Me trae mi padre de Mekness a Nador.

Pasé la frontera andando yo solo, como se cuelan todos los niños allí. Antes estaba la frontera más vieja y no estaba organizada y la policía y la guardia civil están ocupados y te colabas fácilmente sin que se dieran cuenta. Ahora está más complicado.

\section{CUANDO LLEGASTE A MELILLA ¿QUÉ ES LO PRIMERO QUE HICISTE?}

Lo primero que hice fue ir a la Policía Local, porque mi tía me lo explicó. Porque tenías que tener cuidado, hubo gente que fue a la Policía Nacional y los echaron. Y yo ya sabía lo que tenía que hacer. 


\section{2. ¿CONOCÍAS A ALGUIEN QUE HABÍA REALIZADO ESE TRÁMITE?}

Sólo conocía a mi primo. No conocía a nadie más. Ya cuando llegué al centro conocí a más gente.

\section{3. ¿CÓMO LLEGAS AL CENTRO?}

A través de la policía local. Cuando entré a Melilla lo primero que hice fue ir allí y ellos me llevaron al centro.

\section{4. ¿CÓMO ES TU VIDA EN EL CENTRO?}

$\mathrm{Al}$ principio son muchas cosas, tienes que ir adaptándote, el vivir con mucha gente, pero a mí me gustó.

Son muchas cosas que me gustaban del centro, por ejemplo las normas, a mi me gustaba cumplir las normas. A mi me gustaba porque cuando llegas a un sitio tienes que adaptarte y no poner tú tus normas.

Yo hice mi vida, mis estudios, mis cursos, los fines de semana el deporte, me gustaba el baloncesto, todo. Yo soy muy reconocido en el centro por el baloncesto, porque ninguno allí le gustaba el baloncesto y yo siempre estaba con la pelota en la mano. También jugaba con los cadetes en el equipo del Melilla baloncesto. Los educadores del centro me apuntaron al equipo.

No hay nada que no me gustara del centro.

\section{5. ¿QUÉ OPORTUNIDADES TE DIERON EN EL CENTRO?}

Muchas oportunidades. Pude seguir estudiando, no pude estudiar en los colegios de Melilla, pero estuve estudiando allí y así aprendí el castellano, porque cuando vine no conocía nada del idioma. Hice cursos y estudios.

\section{6. ¿HICISTE ALGÚN CURSO DE FORMACIÓN?}

Aprendí el idioma, hice un curso de jardinería, me dieron el diploma y me preguntaron los profesores que si quería seguir estudiando con ellos y así lo hice, seguí en un curso superior de jardinería. También hice un curso de albañil en UGT. También hice uno de pintura, allí mismo en el centro. 


\section{7. ¿CONOCÍAS EL IDIOMA? ¿CÓMO LO APRENDISTE?}

No lo conocía, no hablaba nada. Lo aprendí en el centro porque allí dábamos clase. Tuve facilidades porque sabía hablar francés y me resultó más fácil aprender el español, pero yo no sabía nada del idioma.

18. UNA VEZ QUE LLEGAS A MELILLA, ¿CONSUMES ALGÚN TIPO DE DROGA?

No, yo me sorprendí cuando llegué aquí. Había mucha gente pequeña que salía, que bebía, y yo hasta que cumplí los 19 años no empecé a salir de fiesta y tomar cerveza.

\section{9. ¿QUÉ CAMBIARÍAS DE TU VIDA EN EL CENTRO?}

No tengo nada en concreto que cambiaría. Todo estaba bien para mí, si fueses a preguntar allí por mi te dirán que muy bien y yo digo lo mismo de ellos.

\section{0. ¿CÓMO CONSEGUISTE EL TRABAJO?}

Ahora mismo estoy trabajando con un cuidador de allí del centro, el entró unos meses después de que yo ingresara. Me trató bien, y me dijo que cuando saliese del centro fuera a buscarlo y así lo hice. Cuando salí del centro, me pidieron el pasaporte, me fui a Marruecos cogí el pasaporte, mis papeles, fui a buscarlo y me dio el precontrato de trabajo, me acompañó a entregar los papeles y cuando cogí los papeles empecé a trabajar con él.

\section{1. ¿DÓNDE VIVISTE UNA VEZ QUE CUMPLISTE LA MAYORÍA DE EDAD?}

Otro personal del centro me dejó que viviera en una casa de alquiler que tenía y no me cobró nada, casi dos meses, hasta que conseguí formalizar toda la documentación. Cuando pasaron los dos meses le entregué las llaves.

Son muchas personas los que me han echado una mano y me han ofrecido lo que han podido.

\section{2. ¿PIENSAS QUE TODOS LOS NIÑOS TENÉIS LAS MISMAS OPORTUNIDADES?}


Todos tienen las mismas oportunidades. Si el viene con la idea de buscar una vida mejor, claro que tiene las mismas oportunidades que he tenido yo. Pero si él no lo aprovecha, no va a acabar bien.

\section{3. ¿QUÉ PIENSAS DE OTROS MENORES QUE HAN TENIDO LAS MISMAS OPORTUINIDADES QUE TÚ, PERO NO ESTÁN TRABAJANDO COMO TÚ?}

Los niños que viven en la calle tienen las mismas oportunidades que he tenido yo, pero no quieren ir al centro, quieren quedarse en la calle, porque tienen pájaros en la cabeza, están obsesionados con la Península, no se lo que han visto o lo que creen que hay en la Península, están obsesionados con colarse. Pero si tu no has hecho las cosas bien en tu vida en tu país, tampoco en Melilla y ¿te vas a ir a otro sitio a trabajar?, yo creo que no.

Lo que tienen que hacer es entrar en el centro de menores, aprender el idioma, formarse, sacarse los papeles y ya si quieren irse a otro sitio a trabajar. La verdad que a mí estos niños no me dan pena, me da rabia verlos así por la calle, muchas veces discuto con la gente, porque ¡mira cómo van vestidos!, entran por la frontera y ¿la policía no lo ven por la calle?. Yo por mí los echaría, porque los llevan al centro y se escapan, y realmente hay gente que está necesitada y que quiere aprovechar las oportunidades. Además roban, agreden a personas, que yo lo he visto por la televisión, dan una mala imagen a la ciudad.

\section{4. ¿QUÉ CONSIDERAS QUE HA HECHO QUE TENGAS UNA BUENA INSERCIÓN A DIFERENCIA DE OTRAS PERSONAS QUE NO LO CONSIGUEN?}

Pues portarme bien y hacer lo que me indican. Es como por ejemplo, si te dan un mueble de Ikea con unas instrucciones, pues tienes que seguir las instrucciones para montarlo. Pues esto es lo mismo, hacer todo lo que te indican y así, aprendes de la vida y tienes algo mejor.

\section{5. ¿'TIENES CONTACTO CON TU FAMILIA?}

Si tengo contacto con ellos. Al principio, durante 8 meses no hablé con nadie. Mi padre sabía que estaba aquí, pero mi madre no, porque mi madre me iba a regañar y me iba a decir que por qué me había ido, que no me faltaba de nada, pero ya se me había metido en la cabeza. 
Desde que inicié el contacto ya lo he mantenido. Mi madre también me estuvo mandando dinero mientras estuve aquí, igual que cuando estaba con mi abuela, me mandó un móvil, ropa, dinero, todo lo que me hacía falta.

\section{6. ¿CÓMO TE SIENTES EN MELILLA?}

Me siento bien, si te digo que llevo tres años seguido sin salir a Marruecos y tan a gusto y sin problema.

Estoy bien con la gente, como en todo en la vida hay gente que te mira bien, que te mira mal como en todo la vida, con la mayoría bien.

\section{7. ¿TE GUSTARÍA VOLVER A TU CASA DE NUEVO?}

No, la verdad que no. Mi madre me ofreció vivir con ella en Tánger, porque se casó allí y me dijeron de buscarme un trabajo allí y de quedarme con ellos y le dije que no.

Mi tía también me llamó y me dijo que me fuera con ellos. Ella se ha sacado el bachiller, ha estudiado, ha trabajado, tiene un negocio y me está diciendo que me fuera a trabajar con ella y le dije que no.

Estoy aquí muy a gusto, tengo más libertad, no es igual que en Marruecos, además con esta edad no te vas a ir a vivir a tu casa.

\section{8. ¿CUÁLES SON TUS OBJETIVOS? ¿QUÉ QUIERE CONSEGUIR EN EL FUTURO?}

Pues los sueños básicos tener tu propio trabajo y tu propia casa, casarse y tener hijos.

Me gustaría quedarme en Melilla, no irme a la Península.

\section{ENTREVISTA 8: Dris, 18}

1. ¿DE DONDE ERES?

Soy de Guinea Conakry.

2. ¿CON QUIÉN VIVÍAS EN TU CASA? 
Con mi familia. Mi padre, mi madre y cuatro hermanos en total.

3. ¿TU PADRE Y TU MADRE TRABAJAN?¿TRABAJABAN CUANDO TE VINISTE A MELILLA?

Mi madre era ama de casa y mi padre sí estaba trabajando.

4. ¿CREES QUE TENÍAIS TODO LO NECESARIO PARA VIVIR BIEN? ¿CREES QUE ERA NECESARIO QUE ENTRARA MÁS DINERO EN TU CASA?

Sí, teníamos todo lo necesario para vivir bien.

Mi casa era un piso de tres habitaciones, las dos niñas dormían en una habitación, los dos niños dormíamos en otra y mis padres en la tercera. Tenía un salón, cocina y el cuarto de baño.

5. ¿TE ENCONTRABAS BIEN EN CASA? ¿CÓMO ERA LA RELACIÓN CON TUS PADRES Y CON TUS HERMANOS? (TENÍAS PROBLEMAS EN CASA).

No tanto. No me gustaba estar en casa, pero porque no me gustaba el país. Allí terminas de estudiar, hasta la universidad y ya no tienes trabajo, además había muchas cosas que no me gustaban, como la miseria del país y yo cuando veía en la tele que salían los cantantes con los collares y todo eso ¡a mi me encanta!, veo el dinero y cómo lo gastan y me dio la impresión de que en Europa hay de todo, por eso decido irme de allí.

6. ¿HABÍA UNA BUENA COMUNICACIÓN CON TU FAMILIA, ENTRE TÚ Y TUS PADRES? ¿Y ENTRE TUS PADRES, CÓMO ERA LA RELACIÓN? (VIOLENCIA DE GÉNERO, VIOLENCIA FILIOPARENTAL).

Con mi padre tenía muy buena relación, él me quería mucho. Con quién me llevaba mal era con mi madre. Entiendo que ella quería que siguiera el buen camino, y yo antes de terminar el colegio, antes de salir de mi país, me portaba muy mal y mi madre no quería eso para mí y me pegaba. A veces me pegaba, me chillaba o me tiraba la chancla, o algo así y a mí no me gustaba eso.

Una vez le comenté a mi padre la situación y le regañó. 
La relación con mis hermanos era muy buena, tanto con los mayores, como con los pequeños. Nosotros los hermanos pequeños tenemos respeto hacia los hermanos mayores.

En cuanto a la comunicación en general no teníamos mucha con toda la familia. Cuando llegaba mi padre del trabajo miraba las notas del colegio y a quien tenía buenas notas le recompensaba y a quien no pues le decía algo.

\section{EN TU FAMILIA ¿HABÍA ALGÚN TIPO DE CONSUMO (ANTECEDENTE) DE ALGUNA SUSTANCIA TÓXICA?.}

No en mi familia no. Mi padre fuma tabaco.

\section{8. ¿QUÉ TE MOTIVÓ PARA VENIR A MELILLA?}

Pues por lo que te he comentado antes, a mi no me gustaba mi país. Allí terminas de estudiar, hasta la universidad y ya no tienes trabajo, además había muchas cosas que no me gustaban, como la miseria del país y yo cuando veo en la tele cuando salen los cantantes con los collares y todo eso a mi me encanta, veo el dinero y cómo lo gastan y me dio la impresión de que en Europa hay de todo, por eso decido irme de allí.

Esta información me llega por las redes sociales, Facebook y por televisión.

\section{9. ¿CÓMO ORGANIZASTE TU VIAJE?}

Me levanté por la mañana, cogí unos $600 €$ que tenía guardado de mi padre y me voy de país sin avisar a nadie, ni contar con nadie.

La única compañía que tenía era Google Map. Yo lo que quería era salir de mi país. Llegué a Mali, en ese momento estaban en guerra y te paraban las mafias y te quitaban el dinero, o bien te quedabas allí trabajando para ellos hasta que tuvieras el dinero que te pedían y después ya te dejaban ir, eso es lo que me pasó a mí. Después tardé tres días en atravesar todo el Sahara, lo hice en un camión de arena, pagué y me monté allí con varias personas, entre 100 y 150 personas, luego me senté, todos alineados y cada uno con su agua, garrafas de 5 litros y durante tres días, si el conductor está cansado, puedes bajar. Este camión te deja a $30 \mathrm{~km}$ de la primera ciudad de Argelia y ese trayecto lo haces andando, hasta llegar a Argelia. 
Cuando llegué a Argelia lo primero que hice fue ir a los pisos donde solo viven inmigrantes, alquilé una habitación y estuve allí descansando, comiendo, me pude duchar y ya me quedé tranquilo allí hasta que pensé como me iba a ir de allí, para llegar a Marruecos.

Yo no tenía destino, solo quería salir de mi país, pero una vez que iba avanzando quería seguir un poco más. No tuve conocimiento del centro de menores hasta que llegué a Marruecos, en Rabat, una vez me dijo un amigo que existía Melilla, una frontera entre Marruecos y España, que hay dos caminos para entrar, por el mar o saltar la valla.

Yo crucé pagando a un hombre para poder pasar en el maletero de su coche. Lo hice así porque era muy pequeño y no tenía la fuerza necesaria para saltar la valla. Cuando pasé pillaron al conductor, y éste huyó y yo me quedé allí, no quería salir del maletero. La Guardia Civil me hablaba en francés diciéndome que no pasaba nada que saliera del maletero. Al rato grité y me sacaron del maletero. La Guardia Civil me llevaron a llevó a la comandancia, me estuvieron preguntando muchas cosas y éstos me llevaron a la Policía Nacional, y me preguntaron lo mismo, pero éstos me dieron un sándwich y una coca-cola y al final me comí tres. De ahí me trasladaron a la Policía Local y de allí a La Purísima.

\section{0. ¿ CUÁNDO LLEGAS A MELILLA?}

Con 15 años. Salí de casa con 14 años de mi casa. Llegué el 15 de septiembre de 2014.

Ahora tengo 18 años.

\section{CUANDO LLEGASTE A MELILLA ¿QUÉ ES LO PRIMERO QUE HICISTE?}

Yo crucé pagando a un hombre para poder pasar en el maletero de un coche. Lo hice así porque era muy pequeño y no tenía la fuerza necesaria para saltar la valla. Cuando pasé pillaron al conductor, y éste huyó y yo me quedé allí, no quería salir del maletero. La Guardia Civil me hablaba en francés diciéndome que no pasaba nada que saliera del maletero. Al rato grité y me sacaron del maletero. La Guardia Civil me llevaron a la comandancia, me estuvieron preguntando muchas cosas y éstos me llevaron a la Policía Nacional, y me preguntaron lo mismo, pero éstos me dieron un sándwich y una coca-cola y al final me comí tres. De ahí me trasladaron a la Policía Local y de allí a La Purísima. 


\section{2. ¿CONOCÍAS A ALGUIEN QUE HABÍA REALIZADO ESE TRÁMITE?}

No conocía a nadie que hubiera realizado este trámite antes que yo.

\section{3. ¿CÓMO LLEGAS AL CENTRO?}

Una vez me lleva la Policía Nacional a la Policía Local y de allí a La Purísima.

\section{4. ¿CÓMO ES TU VIDA EN EL CENTRO?}

Los primeros días no estuve bien, solo decía que quería que me llevaran al CETI, porque allí estaban mis compañeros los subsaharianos, no quería estar con los marroquíes.

Al principio no me llevaba con nadie en el centro, pero había una cuidadora que es muy buen gente, que se sentaba conmigo a estudiar, a enseñarme el idioma, me buscaba cursos, me defendía y ...la verdad es que el centro me lo ha dado todo.

\section{5. ¿QUÉ OPORTUNIDADES TE DIERON EN EL CENTRO?}

Me dieron demasiadas. Estoy muy agradecido hacia el personal del centro, sobre todo el director y subdirector, que me dieron la oportunidad de estudiar y de hacer formación profesional, FP y me han ayudado para trabajar. También esa cuidadora que se ha portado muy bien conmigo y que se ha puesto conmigo a estudiar para sacarme la nacionalidad, que ahora tengo el examen.

El 29 de este mes tengo el examen de DNI, las 300 preguntas si apruebo tengo la nacionalidad.

\section{6. ¿HICISTE ALGÚN CURSO DE FORMACIÓN?}

Hice el curso de cocina, de pintura, de mantenimiento.

\section{7. ¿CONOCÍAS EL IDIOMA? ¿CÓMO LO APRENDISTE?}

Yo no hablaba nada de castellano. Yo aprendo el idioma allí en el centro, con la chica esta que te dije que se sentaba conmigo a estudiar.

También me apuntaron a un curso que era para estudiar, para inmigrantes, fue solo un año. Aprendí con la gente, con las películas, con las canciones, que me gustan las canciones de Puerto Rico. 
18. UNA VEZ QUE LLEGAS A MELILLA, ¿CONSUMES ALGÚN TIPO DE DROGA?

Yo no. No fumo nada. Siendo menor de edad no consumía nada, pero ahora siendo mayor de edad sí bebo de vez en cuando.

En el centro nada de nada, sobre todo por esta chica, que siempre me daba consejos y me decía que no quería ver en el parte que yo había hecho algo, había llegado al centro borracho y yo le hacía caso. Ahora todavía me da consejo.

\section{9. ¿QUÉ CAMBIARÍAS DE TU VIDA EN EL CENTRO?}

Cambiaría los niños que se portan mal, a la primera, los niños que roban. Habría que meterlos en un centro de reformatorio, hasta que se recuperen poco a poco, que no puedan salir. Pero que no estén en La Purísima.

\section{0. ¿CÓMO CONSEGUISTE EL TRABAJO?}

Yo mismo me lo he currado y me lo he ganado. Una vez que terminé el curso, hice mi currículo con esta chica del centro. Eché mi currículo en la empresa CLECE y estuve hablando con los empresarios y le expliqué mi situación, que no tenía a nadie en España, que estaba acostumbrado a estar con la gente de Melilla, que por favor me dieran una oportunidad, que tenía el diploma de cocina, que era cocinero o ayudante de cocina. Que solo me quedaban 4 meses de residencia, una vez saliera del centro.

Esto lo repetí en varias ocasiones, ir a hablar con ellos poco a poco, hasta que me aceptaron.

Ya he gestionado la renovación de la documentación y ya tengo fecha para poner la huella.

Hice los trámites yo mismo. Me pidieron muchos papeles, documentos del empresario, pasaporte de mi país, que no lo tengo, me fui a Francia para hacer mi pasaporte en la Embajada. Porque pregunté en la Embajada de Madrid y me dijeron que no lo hacían y hablé con mi padre y me dijo que en Francia sí lo estaban haciendo. Fui a Francia desde Málaga, pero el billete de avión salía muy caro por que no lo saqué con antelación y porque era festivo, así que cogí un autobús hasta Francia. 


\section{1. ¿DÓNDE VIVISTE UNA VEZ QUE CUMPLISTE LA MAYORÍA DE EDAD?}

A través de las redes sociales y la página walapo encontré el piso en el que estoy viviendo. Vivo con un compañero de piso.

\section{2. ¿PIENSAS QUE TODOS LOS NIÑOS TENÉIS LAS MISMAS OPORTUNIDADES?}

Ningún niño puede decir que el centro no está bien. Se come muy bien, mejor que algunos niños de Melilla. Allí por ejemplo, por la mañana tenemos el desayuno, mermelada, chocolate, mantequilla, azúcar, café, cola-cao, tenemos pan, 2 o 3 barras. Lo que tú quieras. Tienes un garrafa de agua allí. La comida va cambiando de menú, hay lentejas, fruta, refrescos. La cena hay hamburguesa con patatas fritas, yogures. Allí nadie puede decir que no come bien, se come genial.

\section{3. ¿QUÉ PIENSAS DE OTROS MENORES QUE HAN TENIDO LAS MISMAS OPORTUINIDADES QUE TÚ, PERO NO ESTÁN TRABAJANDO COMO TÚ?}

Todos tenemos las mismas oportunidades siempre que te portes bien. Allí en el centro no hay diferencia, no hay racismo, da igual de la religión o raza que seas. A todos nos tratan igual.

24. ¿QUÉ CONSIDERAS QUE HA HECHO QUE TENGAS UNA BUENA INSERCIÓN A DIFERENCIA DE OTRAS PERSONAS QUE NO LO CONSIGUEN?

Todo el mundo consigue la documentación, lo que pasa que cuando cumples la mayoría de edad la nueva ley lo que te pide es tu pasaporte, para ver de verdad de qué país eres, si no traes tu pasaporte la extranjería no te puede dar la documentación.

Entonces la edad que tienen los niños en Marrueco no es la misma que aquí, por eso tienen problemas en conseguir la documentación.

Una vez que cumples 18 años le dan la documentación a todo el mundo. 
Para la integración pues no tuve nada de fantasía, me porté bien, respetando a todo el mundo, hice cursos y me ayudaron conseguir el currículo, aunque yo me fui a la empresa para hablar con ellos.

\section{5. ¿TIENES CONTACTO CON TU FAMILIA?}

Sí, hablo a menudo con ellos. Al principio estuve tres meses sin hablar con ellos. Pasado ese tiempo, los llamé y les comenté que me encontraba bien.

\section{6. ¿CÓMO TE SIENTES EN MELILLA?}

En Melilla estoy muy bien, genial. Me gustaría no moverme de aquí, me siento demasiado melillense.

\section{7. ¿TE GUSTARÍA VOLVER A TU CASA DE NUEVO?}

A vivir para siempre no. Solo me gustaría ir de vacaciones. Aquí estoy de lujo.

\section{8. ¿CUÁLES SON TUS OBJETIVOS? ¿QUÉ QUIERE CONSEGUIR EN EL FUTURO?}

Lo primero que quiero es que el 29 tengo el examen de la nacionalidad, una vez que apruebe ese examen, lleva un proceso de documentación, antecedentes penales de mi país, partida de nacimiento, traducido, el padrón y residencia y $100 €$ de tasas, se remite todo al Ministerio de Justicia a Madrid y ya te contestan.

También quiero sacarme $3^{\circ}$ y $4^{\circ}$ de ESO y una vez que lo tenga, me presento a Policía, Militar o Bombero.

\section{9. ¿QUIERES AÑADIR ALGO MÁS?}

Solo quiero decir que los niños del centro comen bien y no los tratan mal y que tienen de todo y que no tienen ningún problema allí. Que todos los trabajadores tratan a todos por igual y muy bien.

\section{0. ¿POR QUÉ PIENSAS QUE LOS NIÑOS SE QUEDAN EN LA CALLE?.}

Porque no tienen experiencia, son niños que se quieren ir a la Península, pero no pueden decir que le tratan mal en el centro. 
Ahora viene la Fiesta y tienen una comida muy buena, tienen de todo.

\section{ENTREVISTA 9: Hakim, 18.}

1. ¿DE DÓNDE ERES?

Soy nacido en Nador, pero me crie en Guercif.

\section{2. ¿CON QUIÉN VIVÍAS EN TU CASA?}

Vivía con mis abuelos, mis tíos, mi madre y dos hermanos, uno mayor y otro más pequeño. Mi madre no estaba mucho por casa, porque trabajaba, era la que llevaba dinero a casa.

Mi madre trabajaba en la frontera con Melilla y no podía venir a diario a Guercif.

Mi padre no llegué a conocerlo.

Mi hermano mayor falleció, porque tenía una enfermedad del corazón y mi hermano pequeño tiene parálisis cerebral. Tengo una hermana en Melilla, hermana por parte de padre, que también tiene la enfermedad del corazón. Yo he salido sano afortunadamente.

\section{3. ¿TU PADRE Y TU MADRE TRABAJAN?¿TRABAJABAN CUANDO TE VINISTE A MELILLA?}

Sí mi madre trabajaba en el contrabando en la frontera con Melilla.

4. ¿CREES QUE TENÍAIS TODO LO NECESARIO PARA VIVIR BIEN? ¿CREES QUE ERA NECESARIO QUE ENTRARA MÁS DINERO EN TU CASA?

Sí, mi abuelo era policía y estábamos bien económicamente y no nos faltaba de nada. Hasta que se torció la cosa cuando yo cumplí los 6 años, porque mi madre ya no tenía tanto trabajo en la frontera, porque estaba cada vez mayor para cargar bultos y mi abuelo se jubiló. En ese momento no teníamos dinero suficiente para vivir todos en casa. Además mi hermano fallece cuando yo tengo 5 años.

Vivimos de la paga de jubilación de mi abuelo que son unos $200 €$ marroquíes. 
5. ¿TE ENCONTRABAS BIEN EN CASA? ¿CÓMO ERA LA RELACIÓN CON TUS PADRES Y CON TUS HERMANOS? (TENÍAS PROBLEMAS EN CASA).

Sí, estaba bien.

6. ¿HABÍA UNA BUENA COMUNICACIÓN CON TU FAMILIA, ENTRE TÚ Y TUS PADRES? ¿Y ENTRE TUS PADRES, CÓMO ERA LA RELACIÓN? (VIOLENCIA DE GÉNERO, VIOLENCIA FILIOPARENTAL).

Con mi familia no ha habido nunca mucha comunicación, el ambiente estaba bien, no había problemas, pero no nos sentábamos a hablar de nuestras cosas.

\section{7. ¿EN TU FAMILIA HABÍA ALGÚN TIPO DE CONSUMO (ANTECEDENTE)} DE ALGUNA SUSTANCIA TÓXICA?.

Sí mi madre fuma tabaco y consume alcohol. Bueno consumía alcohol, llegó a ser alcohólica, ahora ya no, lo dejó.

Tengo un tío que vivía con nosotros en casa, ahora está en la cárcel de Marruecos, que consumía todo tipo de drogas y se metía en todos los líos.

\section{8. ¿QUÉ TE MOTIVÓ PARA VENIR A MELILLA?}

Cuando empieza a entrar menos dinero en casa, es cuando mi abuelo decide que venga a Melilla a buscar una vida mejor, un futuro, para ayudar en casa.

\section{9. ¿CÓMO ORGANIZASTE TU VIAJE?}

Una vez que mi abuelo decide que me venga a Melilla, mi hermana fue a Marruecos a recogerme y es ella la que me trajo a Melilla. Y pasamos la frontera los dos, siendo menores, porque mi hermana seguía siendo menor.

\section{0. ¿ CUÁNDO LLEGAS A MELILLA?}

Entré a Melilla con 6 años. Llego en el 2005.

\section{CUANDO LLEGASTE A MELILLA ¿QUÉ ES LO PRIMERO QUE HICISTE?}

Estuvimos pensando a ver cómo se podía entrar en el centro Gota de Leche. Nos dirigimos a la Consejería de menores, y les dijo mi tía que no se podía hacer cargo de mí, pero le dijeron que no, en la Gota de Leche había en ese momento muchos niños, cuando se 
quedara un sitio libre me llevaban allí. Y me llevaron al centro La Purísima y estuve allí dos años.

\section{2. ¿CONOCÍAS A ALGUIEN QUE HABÍA REALIZADO ESE TRÁMITE?}

Mi hermana mayor ya estaba aquí en Melilla. Ella vino con 14 años. Vino porque una tía mía vivía aquí. Ya a los 18 años se casó en Melilla y ya se quedó aquí.

Antes de que viniera mi hermana, teníamos una tía y un primo que habían venido antes a Melilla, aunque no vinieron a través del centro.

\section{3. ¿CÓMO LLEGAS AL CENTRO?}

Mi tía me llevó a Consejería, para decirle que no se podía hacer cargo de mí. Me llevaron directamente a La Purísima, a la espera de que se quedara un plaza libre en La Gota de Leche.

\section{4. ¿CÓMO ES TU VIDA EN EL CENTRO?}

Los dos años del centro La Purísima estuve muy mal. Me escapaba continuamente, dormía en la calle, mi familia no sabía nada de mí.

Me iba a la calle porque ese centro no está bien. Es un centro que no es como La Gota de Leche, que tenga unas normas que se lleven a raja tabla, cada uno va a su bola. La educación no es buena, no se usa la comunicación como en La Gota de Leche.

Mi madre entró a Melilla a buscarme, porque se enteró de que estaba durmiendo en la calle y me encontró en la playa San Lorenzo durmiendo en una hamaca.

Conocí a unos niños que vivían en Cañada, entonces pasaba todo el día con ellos y a última hora su madre me llevaba al centro.

A los 8 años me llevan al Pabellón de niños de La Gota de Leche.

En La Gota de Leche tuve la estabilidad que yo buscaba, allí todo estaba muy bien. Me llevaban todas las mañanas al colegio, me recogían. Por las tardes estudiábamos. Hacíamos 
actividades en verano, íbamos de viaje. Todo más estable, mucho mejor y con unas normas que se podía seguir y si hacías algo mal tenías un castigo.

\section{5. ¿QUÉ OPORTUNIDADES TE DIERON EN EL CENTRO?}

Una oportunidad de tener un futuro mejor, una infancia mejor, una adolescencia mejor. Tener una estabilidad y tener la oportunidad de poder pensar en un futuro. Te dan todo lo que necesitamos los niños y los adolescentes. Nos lo dan todo.

\section{6. ¿HICISTE ALGÚN CURSO DE FORMACIÓN?}

Tengo la ESO. Hice un curso de comercio y marketing y ahora voy a hacer un curso de primeros auxilios de la Cruz Roja, porque quiero sacarme el título de socorrista.

\section{7. ¿CONOCÍAS EL IDIOMA? ¿CÓMO LO APRENDISTE?}

Cuando llegué no conocía el idioma, pero lo aprendí muy rápido. Mientras estuve en La Purísima, no iba mucho al colegio, porque no iba. Como no pronunciaba bien algunas letras, me llevaron a la logopeda del colegio aprendí el idioma más rápido.

Yo era el niño mimado de algunas personas en el centro de La Purísima y había algunos trabajadores que se sentaban conmigo a hacer las tareas y a aprender el idioma.

18. UNA VEZ QUE LLEGAS A MELILLA, ¿CONSUMES ALGÚN TIPO DE DROGA?

No, no consumo nunca nada.

\section{9. ¿QUÉ CAMBIARÍAS DE TU VIDA EN EL CENTRO?}

El horario no me gustó, pero entiendo que es el adecuado para nuestra edad. Nada más.

\section{0. ¿CÓMO CONSEGUISTE EL TRABAJO?}

A través de relacionarme con la gente adecuada y hacer formación y portarme bien con la gente.

\section{1. ¿DÓNDE VIVISTE UNA VEZ QUE CUMPLISTE LA MAYORÍA DE EDAD?}

Viví con mi hermana que vive en Melilla, estoy en su casa. No he tenido que buscar ninguna casa. 
22. ¿PIENSAS QUE TODOS LOS NIÑOS TENÉIS LAS MISMAS OPORTUNIDADES?

Todos tenemos las mismas oportunidades, solo que tienes que tener las cosas claras y tienes que ser espabilado para poder relacionarse con gente.

\section{3. ¿QUÉ PIENSAS DE OTROS MENORES QUE HAN TENIDO LAS MISMAS OPORTUINIDADES QUE TÚ, PERO NO ESTÁN TRABAJANDO COMO TÚ?}

Porque hay mucha gente que viene para pasar el tiempo y encuentran la comodidad de estar en el centro con todo hecho y no se esfuerzan por hacer nada por ellos. Y se les pasa el tiempo.

\section{4. ¿QUÉ CONSIDERAS QUE HA HECHO QUE TENGAS UNA BUENA INSERCIÓN A DIFERENCIA DE OTRAS PERSONAS QUE NO LO CONSIGUEN?}

Es necesario tener las cosas claras y no estar todo el día tumbados, de no acomodarse de tenerlo todo a mano. Cuando tienen 17 años se dan cuenta y empiezan las madres mías y se ponen a hacer cosas, ya no da tiempo, tienes que hacerlo desde el principio.

También depende de la personalidad de cada niño, porque tienes que ser espabilado para poder relacionarte con gente y así poder encontrar un trabajo.

Hay que seguir las normas, no liarla, no tener problemas con nadie, hacer caso a los educadores, y currártelo.

\section{5. ¿TIENES CONTACTO CON TU FAMILIA?}

Sí sigo teniendo contacto con ellos, es más ahora mi madre está aquí en Melilla y además está aquí trabajando.

\section{6. ¿CÓMO TE SIENTES EN MELILLA?}

En Melilla estoy bien, pero no me gusta, creo que fuera en la Península voy a tener más oportunidades en todo. 
No he vivido en la Península, pero he viajado mucho y lo veo así. Me gusta más el ambiente.

\section{7. ¿TE GUSTARÍA VOLVER A TU CASA DE NUEVO?}

No me gustaría volver a Marruecos, no me gusta ese País, si aquí creo que hay pocas oportunidades, imagínate allí. En Marruecos por todo tienes que pagar, hasta por tu documentación.

Los sueldos son muy bajos. No hay estudios, te da menos oportunidades.

\section{8. ¿CUÁLES SON TUS OBJETIVOS? ¿QUÉ QUIERE CONSEGUIR EN EL FUTURO?}

Mis metas son seguir jugando al fútbol. Poder sacarme más estudios.

Quiero conseguir un trabajo mejor que me pueda permitir mis caprichos y tener una vida estable.

\section{9. ¿QUÉ LE DIRÍAS A LOS NIÑOS QUE ESTÁN EN LA CALLE?}

Les aconsejaría que entraran al centro. Le diría que entrara en La Purísima por la documentación, porque aquí el tener documentación es muy importante. Y que aprovechen las oportunidades que le dan, porque aquí en Melilla los trámites son más lentos y cuando salgan le van a quedar tres meses de documentación y no van a tener tiempo de estudiar, buscar un trabajo, eso lo tienen que hacer mientras están en el centro.

\section{ENTREVISTA 10: Yaser, 18.}

\section{1. ¿DE DÓNDE ERES?}

De Jenifra.

\section{2. ¿CON QUIÉN VIVÍAS EN TU CASA?}

Vivía con mi tía. Mi madre falleció. Cuando mi madre falleció mi padre se fue a otro sitio. Tengo cinco hermanos, pero estábamos una vez que fallece mi madre todos nos separamos. Yo soy el más pequeño. 
3. ¿CREES QUE TENÍAIS TODO LO NECESARIO PARA VIVIR BIEN? ¿CREES QUE ERA NECESARIO QUE ENTRARA MÁS DINERO EN TU CASA?

Con mi tía no me faltaba de nada para vivir. No me faltaba nada. Además me trajo aquí a Melilla con otra tía y vivía aquí con ella.

4. ¿TE ENCONTRABAS BIEN EN CASA? ¿CÓMO ERA LA RELACIÓN CON TUS PADRES Y CON TUS HERMANOS? (TENÍAS PROBLEMAS EN CASA).

Sí estoy bien en la casa de mi tía de Melilla, con mi tía de Marruecos no estuve mucho tiempo. Pero es que era muy pequeño, yo no sabía nada.

5. ¿HABÍA UNA BUENA COMUNICACIÓN CON TU FAMILIA, ENTRE TÚ Y TUS PADRES? ¿Y ENTRE TUS PADRES, CÓMO ERA LA RELACIÓN? (VIOLENCIA DE GÉNERO, VIOLENCIA FILIOPARENTAL).

Yo era muy pequeño, no me acuerdo mucho, pero no tenía ningún problema.

6. ¿EN TU FAMILIA HABÍA ALGÚN TIPO DE CONSUMO (ANTECEDENTE) DE ALGUNA SUSTANCIA TÓXICA?.

No, nadie que yo sepa. Mi tía no consumía ningún tipo de sustancia.

7. ¿QUÉ TE MOTIVÓ PARA VENIR A MELILLA?

Yo no decidí venir a Melilla a mi me trajeron para vivir con mi tía, pero al final entré en el centro porque la policía me vio varias veces por la calle sin documentación.

8. ¿CÓMO ORGANIZASTE TU VIAJE?

No organizo nada, puesto que la decisión de venirme no fue mía.

9. ¿ CUÁNDO LLEGAS A MELILLA?

Llego a Melilla con 7 años.

10. CUANDO LLEGASTE A MELILLA ¿QUÉ ES LO PRIMERO QUE HICISTE?

Me fui a casa de una tía en Marruecos y ella me trae con unos 7 años a casa de una tía aquí en Melilla.

Ahora tengo 18 años. 


\section{1. ¿CONOCÍAS A ALGUIEN QUE HABÍA REALIZADO ESE TRÁMITE?}

No, conocía a nadie antes de venir a Melilla.

Antes de entrar en el centro sí conocía a niños de Melilla porque salía a jugar a la calle, cuando estuve en la casa de mi tía.

En ningún momento supe, antes de entrar al centro, que había un centro de menores, es más pasaba por ahí y yo no sabía que era un centro.

\section{2. ¿CÓMO LLEGAS AL CENTRO?}

Llegué al centro porque la Policía me pilló muchas veces por la calle, me pedía la documentación y al no tenerla, me subió a La Purísima. Cada vez que me llevaban al centro yo me escapaba, hasta que me llevaron una vez al centro Gota de Leche, en el Pabellón de niños, y allí era encerrado y no tuve la oportunidad de escaparme y allí me quedé.

Entré al centro con 9 años.

\section{3. ¿CÓMO ES TU VIDA EN EL CENTRO?}

$\mathrm{Al}$ principio cuando estuve en el centro quería escaparme, pero después de hablar con los niños me dijeron que era mejor que me quedara para poder conseguir los papeles.

Al principio no me gustó nada, de hecho quise escaparme, pero no pude porque era encerrado. Además me castigaban.

\section{4. ¿QUÉ OPORTUNIDADES TE DIERON EN EL CENTRO?}

En el centro jugaba al fútbol, me pusieron en contacto con el equipo del Rusadir y jugaba con ellos, pero lo dejaba.

He podido estudiar.

\section{5. ¿HICISTE ALGÚN CURSO DE FORMACIÓN?}

He hecho cursos de cocina, otro curso de camarero, otro curso de la obra. Han sido PCPI. 
También estudié en el colegio y tengo la ESO.

\section{6. ¿CONOCÍAS EL IDIOMA? ¿CÓMO LO APRENDISTE?}

Antes de venir a Melilla no sabía nada del idioma, pero cuando estuve aquí un tiempo con mi tía de Melilla aprendí algo del idioma. Por eso entre al centro sabiendo hablar algo.

En el centro es cuando aprendo a hablar bien. Aprendí en el colegio.

\section{UNA VEZ QUE LLEGAS A MELILLA, ¿CONSUMES ALGÚN TIPO DE DROGA?}

No he consumido ningún tipo de sustancia.

\section{8. ¿QUÉ CAMBIARÍAS DE TU VIDA EN EL CENTRO?}

No cambiaría nada de mi vida en el centro, estuve bien.

\section{9. ¿CÓMO CONSEGUISTE EL TRABAJO?}

Mi hermana me ha echado una mano y tengo cerrado un trabajo allí en Palencia donde está ella. Porque ella está trabajando allí.

\section{0. ¿DÓNDE VIVISTE UNA VEZ QUE CUMPLISTE LA MAYORÍA DE EDAD?}

No, tengo problema porque aquí tengo a mi tía y además mi hermana ya está instalada en Palencia.

En cuanto a la residencia tampoco tengo problema porque tengo la residencia permanente.

\section{1. ¿PIENSAS QUE TODOS LOS NIÑOS TENÉIS LAS MISMAS OPORTUNIDADES?}

Es importante venir pequeño, si vienes con 17 años te dan la residencia solo para 6 meses y hay veces que cuando sales del centro la residencia está caducada. Si vienes de pequeño y te quedas en el centro, cumpliendo las normas, consigues la residencia permanente.

22. ¿QUÉ PIENSAS DE OTROS MENORES QUE HAN TENIDO LAS MISMAS OPORTUINIDADES QUE TÚ, PERO NO ESTÁN TRABAJANDO COMO TÚ? 
En el centro de Gota de Leche muchos. En La Purísima pocos. Porque no les gusta estar en ese centro, hay algunos niños que se quieren ir a la Península.

23. ¿QUÉ CONSIDERAS QUE HA HECHO QUE TENGAS UNA BUENA INSERCIÓN A DIFERENCIA DE OTRAS PERSONAS QUE NO LO CONSIGUEN?

No he hecho nada especial. Solo he estado en el centro sin hacer baja -no dormir en el centro y estar sin aparecer por allí durante 6 meses-. Seguir las normas, estudiar, no crear problemas.

\section{4. ¿'TIENES CONTACTO CON TU FAMILIA?}

Cuando desde La Gota de Leche salíamos a jugar al parque veía a mi prima, a través de ella pude avisar a mi tía de que estaba en el centro y mantenía el contacto con mi tía.

Ahora voy verla con frecuencia.

Con mi padre hablo de vez en cuando por teléfono. Como está en Marruecos no he podido ir a verlo. Él tampoco ha podido venir a verme porque no tiene pasaporte.

\section{5. ¿CÓMO TE SIENTES EN MELILLA?}

Yo estoy muy bien en Melilla, me he criado aquí. Estoy acostumbrado a Melilla, cuando me voy de viaje, siempre quiero volver.

\section{6. ¿TE GUSTARÍA VOLVER A TU CASA DE NUEVO?}

No, me gustaría quedarme en Melilla. Me he criado aquí.

\section{7. ¿CUÁLES SON TUS OBJETIVOS? ¿QUÉ QUIERE CONSEGUIR EN EL FUTURO?}

Me gustaría irme a la Península. Mi hermana está allí, porque ella entró en el centro una semana más tarde de que yo ingresara.

Quiero trabajar para tener una casa, una mujer, una familia.

28. ¿QUÉ LE DIRÍAS A LOS NIÑOS QUE ESTÁN EN LA CALLE? 
Que se queden aquí a estudiar. Pero ellos quieren entrar en Gota de Leche o irse fuera, no quieren entrar en La Purísima. 